Prepared in cooperation with the City and Borough of Juneau

\title{
Hydrology and Flood Profiles of Duck Creek and Jordan Creek Downstream from Egan Drive, Juneau, Alaska
}

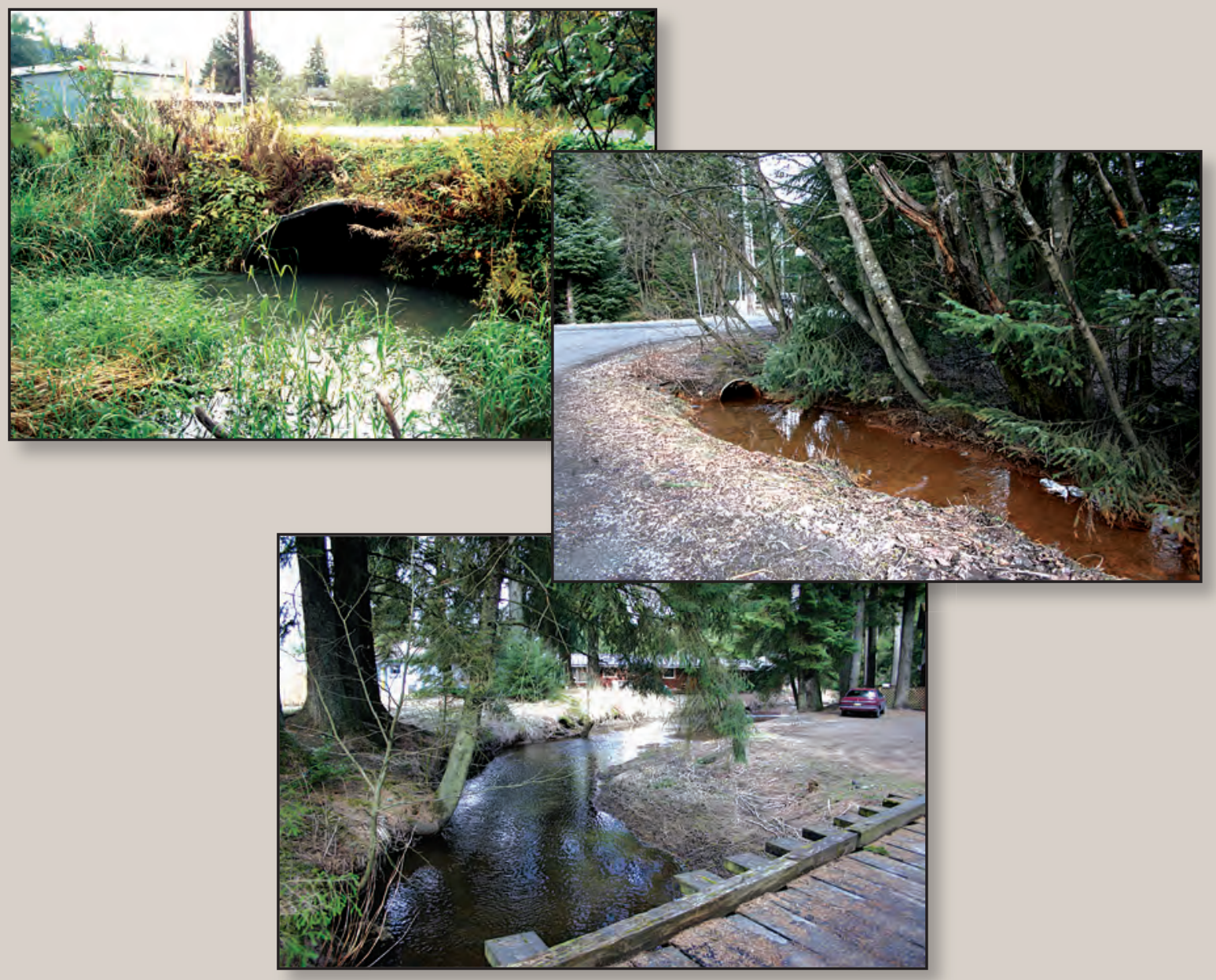

Scientific Investigations Report 2006-5323 
Cover: Photographs of channel and structures, Juneau, Alaska, from top to bottom: (1) Duck Creek at a private driveway upstream from Berners Avenue (photograph by Janet Curran, U.S. Geological Survey, September 24, 2004). (2) Unnamed Tributary to Duck Creek at North El Camino Street, and (3) Jordan Creek at a private driveway downstream from Jordan Avenue (photographs by Daniel Long, U.S. Geological Survey, March 27, 2005). 


\section{Hydrology and Flood Profiles of Duck Creek and Jordan Creek Downstream from Egan Drive, Juneau, Alaska}

Janet H. Curran

Prepared in cooperation with the City and Borough of Juneau

Scientific Investigations Report 2006-5323 


\title{
U.S. Department of the Interior DIRK KEMPTHORNE, Secretary
}

\author{
U.S. Geological Survey \\ Mark D. Myers, Director
}

\section{U.S. Geological Survey, Reston, Virginia: 2007}

For product and ordering information:

World Wide Web: http://www.usgs.gov/pubprod

Telephone: 1-888-ASK-USGS

For more information on the USGS--the Federal source for science about the Earth, its natural and living resources, natural hazards, and the environment:

World Wide Web: http://www.usgs.gov

Telephone: 1-888-ASK-USGS

Any use of trade, product, or firm names is for descriptive purposes only and does not imply endorsement by the U.S. Government.

Although this report is in the public domain, permission must be secured from the individual copyright owners to reproduce any copyrighted materials contained within this report.

Curran, J.H., 2007, Hydrology and flood profiles of Duck Creek and Jordan Creek downstream from Egan Drive, Juneau, Alaska: U.S. Geological Survey Scientific Investigations Report 2006-5323, 35 p. 


\section{Contents}

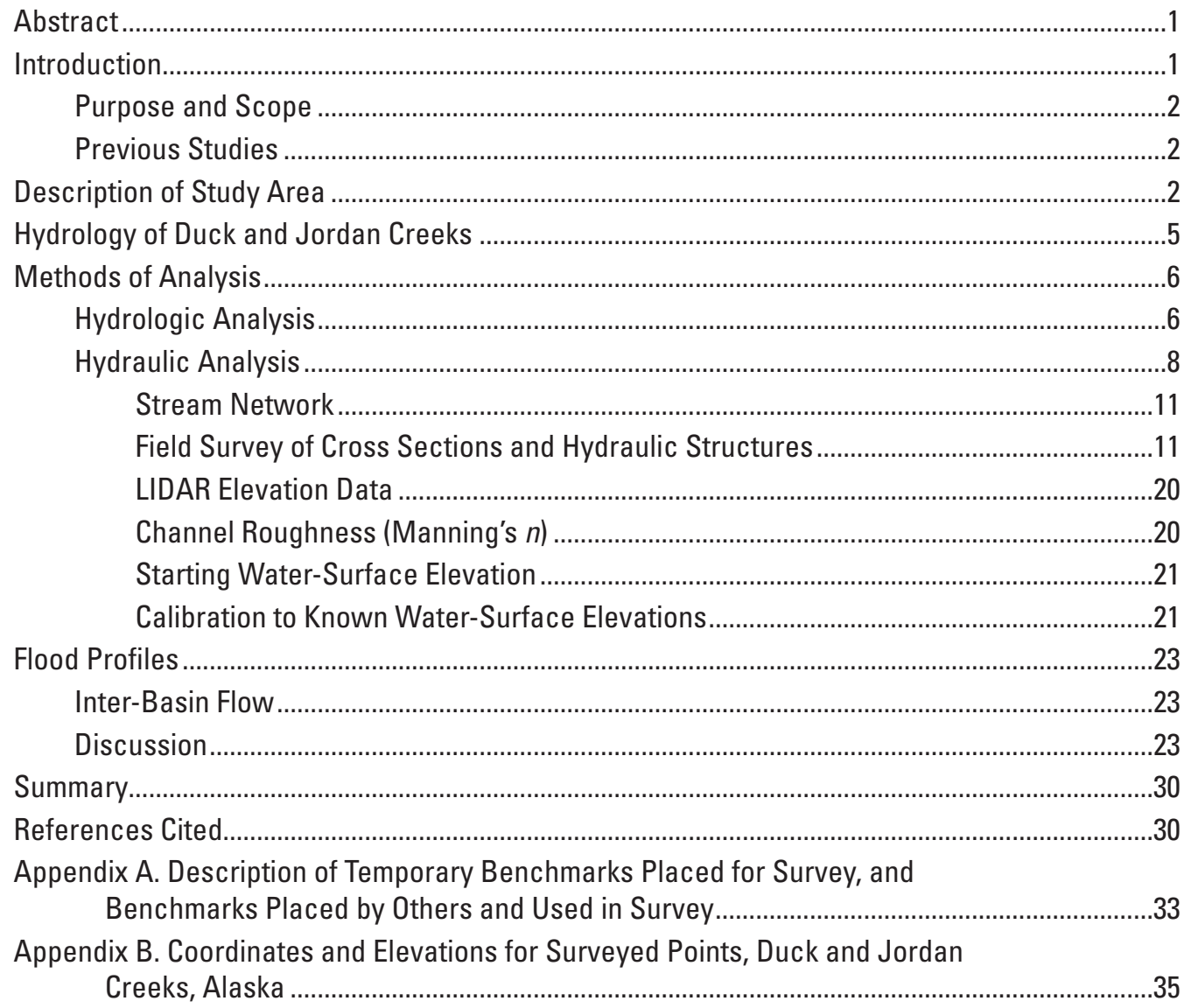




\section{Figures}

Figure 1. Map showing location of Duck and Jordan Creeks, Juneau, Alaska $\ldots \ldots \ldots \ldots \ldots . . \ldots$

Figure 2. Map showing location of stream-gaging stations, bridges, and culverts along Duck and Jordan Creeks, Juneau, Alaska....

Figure 3. Photographs showing view of channel and structures along $(A)$ Duck Creek at a private driveway upstream from Berners Avenue, $(B)$ Unnamed Tributary to Duck Creek at North El Camino Street, and $(C)$ Jordan Creek at a private driveway downstream from Jordan Avenue, Juneau, Alaska

Figure 4. Graph showing annual maximum instantaneous peak streamflow for Duck and Jordan Creeks, Juneau, Alaska

Figure 5. Map showing modeled stream center lines and general elevation data for Duck and Jordan Creeks, Juneau, Alaska...

Figure 6. Maps showing locations of modeled and surveyed cross sections along $(A-D)$ Duck Creek and ( $E-F)$ Jordan Creek, Juneau, Alaska

Figure 7. Graph showing profile of simulated water-surface elevations and measured water-surface elevations for flow in Duck and Jordan Creeks, Juneau, Alaska, November 21, 2005

Figure 8. Grpahs showing flood profiles for Duck and Jordan Creeks, and unnamed tributary to Duck Creek, Juneau, Alaska

Figure 9. Map showing modeled stream center lines, roads, general elevation data, and direction ofinter-basin flow for Duck and Jordan Creeks between Egan

Drive and Glacier Highway in Juneau, Alaska

\section{Tables}

Table 1. Annual maximum instantaneous peak streamflow for Duck and Jordan Creeks, Juneau, Alaska

Table 2. Peak streamflow estimated from streamflow data and regional equations for selected recurrence intervals, Duck and Jordan Creeks, Juneau, Alaska

Table 3. Basin characteristics for Duck and Jordan Creeks, Juneau, Alaska $\quad . . \ldots \ldots \ldots \ldots . . . .8$

Table 4. Measured streamflows and corresponding simulated streamflows using drainage-area ratios, Duck Creek, Juneau, Alaska

Table 5. Streamflows used for hydraulic model, Duck and Jordan Creeks, Juneau, Alaska 10

Table 6. Index to cross section identifiers, Duck and Jordan Creeks, Juneau, Alaska ..... 19

Table 7. Range of Manning's $n$ for Duck and Jordan Creeks, Alaska ................... 21

Table 8. Comparison of flood profiles at limits of study area to adjacent published profiles, Duck and Jordan Creeks, Juneau, Alaska 


\section{Conversion Factors, Datums, and Abbreviations and Acronyms}

Conversion Factors

\begin{tabular}{lcl}
\hline Multiply & By & To obtain \\
\hline cubic foot per second $\left(\mathrm{ft}^{3} / \mathrm{s}\right)$ & 0.02832 & cubic meter per second \\
foot (ft) & 0.3048 & meter \\
inch (in.) & 2.54 & centimeter \\
inch (in.) & 25.4 & millimeter \\
mile (mi) & 1.609 & kilometer \\
square mile $\left(\mathrm{mi}^{2}\right)$ & 259.0 & hectare \\
square mile $\left(\mathrm{mi}^{2}\right)$ & 2.590 & square kilometer \\
\hline
\end{tabular}

Temperature in degrees Celsius $\left({ }^{\circ} \mathrm{C}\right)$ may be converted to degrees Fahrenheit $\left({ }^{\circ} \mathrm{F}\right)$ as follows:

$$
{ }^{\circ} \mathrm{F}=\left(1.8 \mathrm{x}^{\circ} \mathrm{C}\right)+32 .
$$

Temperature in degrees Fahrenheit $\left({ }^{\circ} \mathrm{F}\right)$ may be converted to degrees Celsius $\left({ }^{\circ} \mathrm{C}\right)$ as follows:

$$
{ }^{\circ} \mathrm{C}=\left({ }^{\circ} \mathrm{F}-32\right) / 1.8 \text {. }
$$

Datums

Vertical coordinate information is referenced to Mean Lower Low Water (MLLW).

Horizontal coordinate information is referenced to the North American Datum of 1983 (NAD 83).

Altitude, as used in this report, refers to distance above the vertical datum.

Abbreviations and Acronyms

\begin{tabular}{ll}
\hline $\begin{array}{l}\text { Abbreviations } \\
\text { and Acronyms }\end{array}$ & \\
\hline AKDOTPF & Alaska Department of Transportation and Public Facilities \\
CORS & Continuously Operating Reference Stations \\
FEMA & Federal Emergency Management Agency \\
FIS & Flood Insurance Study \\
GPS & Global Positioning System \\
HEC-RAS & U.S. Army Corps of Engineers' Hydrologic Engineering Center River Analysis System \\
LIDAR & Light Detection and Ranging \\
NGS & National Geodetic Survey \\
RTK & Real-Time Kinetic \\
USGS & U.S. Geological Survey \\
\hline
\end{tabular}


This page is intentionally left blank. 


\title{
Hydrology and Flood Profiles of Duck Creek and Jordan Creek Downstream from Egan Drive, Juneau, Alaska
}

\author{
By Janet H. Curran
}

\section{Abstract}

Hydrologic and hydraulic updates for Duck Creek and the lower part of Jordan Creek in Juneau, Alaska, included computation of new estimates of peak streamflow magnitudes and new water-surface profiles for the 10-, 50-, 100-, and 500-year floods. Computations for the 2-, 5-, 10-, 25-, 50-, 100-, 200-, and 500-year recurrence interval flood magnitudes for both streams used data from U.S. Geological Survey stream-gaging stations weighted with regional regression equations for southeast Alaska. The study area for the hydraulic model consisted of three channels: Duck Creek from Taku Boulevard near the stream's headwaters to Radcliffe Road near the end of the Juneau International Airport runway, an unnamed tributary to Duck Creek from Valley Boulevard to its confluence with Duck Creek, and Jordan Creek from a pedestrian bridge upstream from Egan Drive to Crest Street at Juneau International Airport. Field surveys throughout the study area provided channel geometry for 206 cross sections, and geometric and hydraulic characteristics for 29 culverts and 15 roadway, driveway, or pedestrian bridges. Hydraulic modeling consisted of application of the U.S. Army Corps of Engineers' Hydrologic Engineering Center River Analysis System (HEC-RAS) for steady-state flow at the selected recurrence intervals using an assumed high tide of 20 feet and roughness coefficients refined by calibration to measured water-surface elevations from a 2- to 5-year flood that occurred on November 21, 2005. Model simulation results identify inter-basin flow from Jordan Creek to the southeast at Egan Drive and from Duck Creek to Jordan Creek downstream from Egan Drive at selected recurrence intervals.

\section{Introduction}

Duck and Jordan Creeks flow through a low-lying, urban to suburban environment in Juneau's Mendenhall Valley, presenting flood hazards to traffic, structures, and properties.
Flood plain mapping provides a means to mitigate and manage such flood hazards, but agencies must revise maps to reflect new data and natural or engineered environment changes. The U.S. Geological Survey (USGS), in cooperation with the City and Borough of Juneau, Alaska, began a study in 2004 to update hydrologic and hydraulic analyses in support of flood plain mapping updates. This study took advantage of newly available streamflow data and assessed the present configuration of culverts and bridges.

The two streams flow several miles through the Mendenhall Valley, a broad, recently deglaciated valley, and continue another mile over a broad, low-lying plain before discharging into salt or brackish water near Fritz Cove. Duck Creek and the lower part of Jordan Creek lie within an urban to suburban environment, including residential and commercial properties and the Juneau International Airport. Culverts, road bridges, and pedestrian bridges cross the streams an average of every $600 \mathrm{ft}$ in the study area. Flooding along both streams periodically overtops roadways and encroaches on streamside properties and structures. To manage and mitigate these flood hazards, the City and Borough of Juneau is participating in a process to revise flood plain maps for many local streams, including Duck and Jordan Creeks.

Many cities formalize flood plain mapping by participating in the Federal Emergency Management Agency National Flood Insurance Program. A Flood Insurance Study (FIS) documents an investigation of the extent of flooding expected during floods of various magnitudes. The most recent FIS for the City and Borough of Juneau, updated in 1990 (Federal Emergency Management Agency, 1990), maps flood plain areas along Duck and Jordan Creeks. The FIS indicates the streams' flood plains may merge in part of their lower reaches. New USGS streamflow data, channel changes, and engineered structure changes prompted the City and Borough of Juneau to seek a hydrologic and hydraulic analysis of Duck Creek and the lower reaches of Jordan Creek to help update flood plain maps. 


\section{Purpose and Scope}

The purpose of this study was to provide hydrologic and hydraulic analyses to assist the City and Borough of Juneau with a re-analysis of the flood plains adjacent to Duck Creek and the lower reaches of Jordan Creek. This report describes the methods for and results of a flood frequency analysis using data from stream-gaging stations and regional regression equations. The report also describes the methods for and results of development of a flood profile from a onedimensional hydraulic model using the U.S. Army Corps of Engineers' computer program Hydrologic Engineering Center River Analysis System (HEC-RAS). The study focuses on Duck Creek, including Duck Creek and that part of Jordan Creek where its flood plain could merge with Duck Creek's at higher flows. Additional work will be required to update Jordan Creek upstream from Egan Drive.

\section{Previous Studies}

The existing City and Borough of Juneau FIS (Federal Emergency Management Agency, 1990) pre-dated the USGS stream-gaging stations on Duck or Jordan Creeks. Recognizing the potential for inter-basin transfer of flood flows between Duck and Jordan Creeks and the potential for storage of flood flows, that report includes a customized hydrologic analysis to modify discharges initially modeled from precipitation. The analysis identified several major control areas spanning both streams, in particular Berners Avenue/Glacier Highway and Egan Drive. Rating curves relating water-surface elevation to discharge were developed for each limiting engineered structure—bridge, culvert, or roadway where weir flow could occur-within the control areas. Combined rating curves determined the outflow from each control area. The effects of storage for these control areas and for other storage areas were simulated, and a Corps of Engineers computer program was applied to route the flows and determine the effect on the hydrograph (Federal Emergency Management Agency, 1990). This effort resulted in reducing the estimated combined 100-year flood for the two streams from 1,200 to $699 \mathrm{ft}^{3} / \mathrm{s}$. The tidal elevation used as a starting water surface for Duck and Jordan Creeks was $20 \mathrm{ft}$, stated as the high tide that would occur during a month when the selected floods would occur.

An updated hydrologic and hydraulic analysis for the Mendenhall River (Neal and Host, 1999) indicates that channel incision is associated with high regional rates of landsurface uplift. Although uplift equally affects the Mendenhall Valley, Duck and Jordan Creeks have a much more limited capacity for incision. The gentle gradients, low velocities, and locally dense in-stream vegetation along these smaller streams may limit channel erosion to local scour.

\section{Description of Study Area}

The City and Borough of Juneau, along Gastineau Channel in southeast Alaska (fig. 1), is Alaska's capital and the largest population center in the southeastern part of the state. Duck and Jordan Creeks flow through the eastern side of Juneau's Mendenhall Valley (fig. 2). Mendenhall Valley originates at the Mendenhall Glacier about 10 mi northwest of downtown Juneau. East Mendenhall Valley is a developed residential and commercial area with a population of 12,122 in 2001 (City and Borough of Juneau, Alaska, 2001, accessed March 2, 2006), or more than one-third of the City and Borough of Juneau population.

Duck and Jordan Creeks occupy adjacent drainage basins of 1.3 and $2.6 \mathrm{mi}^{2}$, respectively, east of the Mendenhall River and south of the Mendenhall Glacier. The streams' headwaters lie along the forested eastern flanks of the valley, which rise abruptly to an elevation of over 2,900 ft at the summit of Thunder Mountain. Duck Creek first becomes channelized within the developed valley floor, where surrounding land elevations are about $60 \mathrm{ft}$. Jordan Creek originates on the east flank of the valley wall and flows through a narrow strip of undeveloped muskeg and spruce forest within the Tongass National Forest before emerging into developed areas upstream from Egan Drive.

The study area consists of channel and flood plain areas along Duck Creek and along the reaches of Jordan Creek where the two streams' flood plains could merge. Specifically, the study area consists of the main stem of Duck Creek (fig. 3A), a short tributary to Duck Creek, termed Unnamed Tributary to Duck Creek in this report (fig. 3B), and the main stem of Jordan Creek (fig. 3C). The modeled reach of Duck Creek is $3.4 \mathrm{mi}$ long, extending from $40 \mathrm{ft}$ upstream from Taku Boulevard to $40 \mathrm{ft}$ downstream from Radcliffe Road at the end of the Juneau International Airport runway. The modeled reach of Unnamed Tributary to Duck Creek is $0.3 \mathrm{mi}$ long, extending from $220 \mathrm{ft}$ downstream from Valley Boulevard to a pond upstream from McGinnis Drive. The modeled reach of Jordan Creek is $1.1 \mathrm{mi}$ long, extending from $370 \mathrm{ft}$ upstream from Egan Drive to $50 \mathrm{ft}$ downstream from Crest Street, within the perimeter of the Juneau International Airport. An additional, unnamed tributary to Duck Creek near Nancy Street was included in the previous FIS as East Fork Duck Creek, but was omitted from the study area for this report. This tributary drains a highly engineered environment dominated by a series of ponds formed in former gravel pits. 


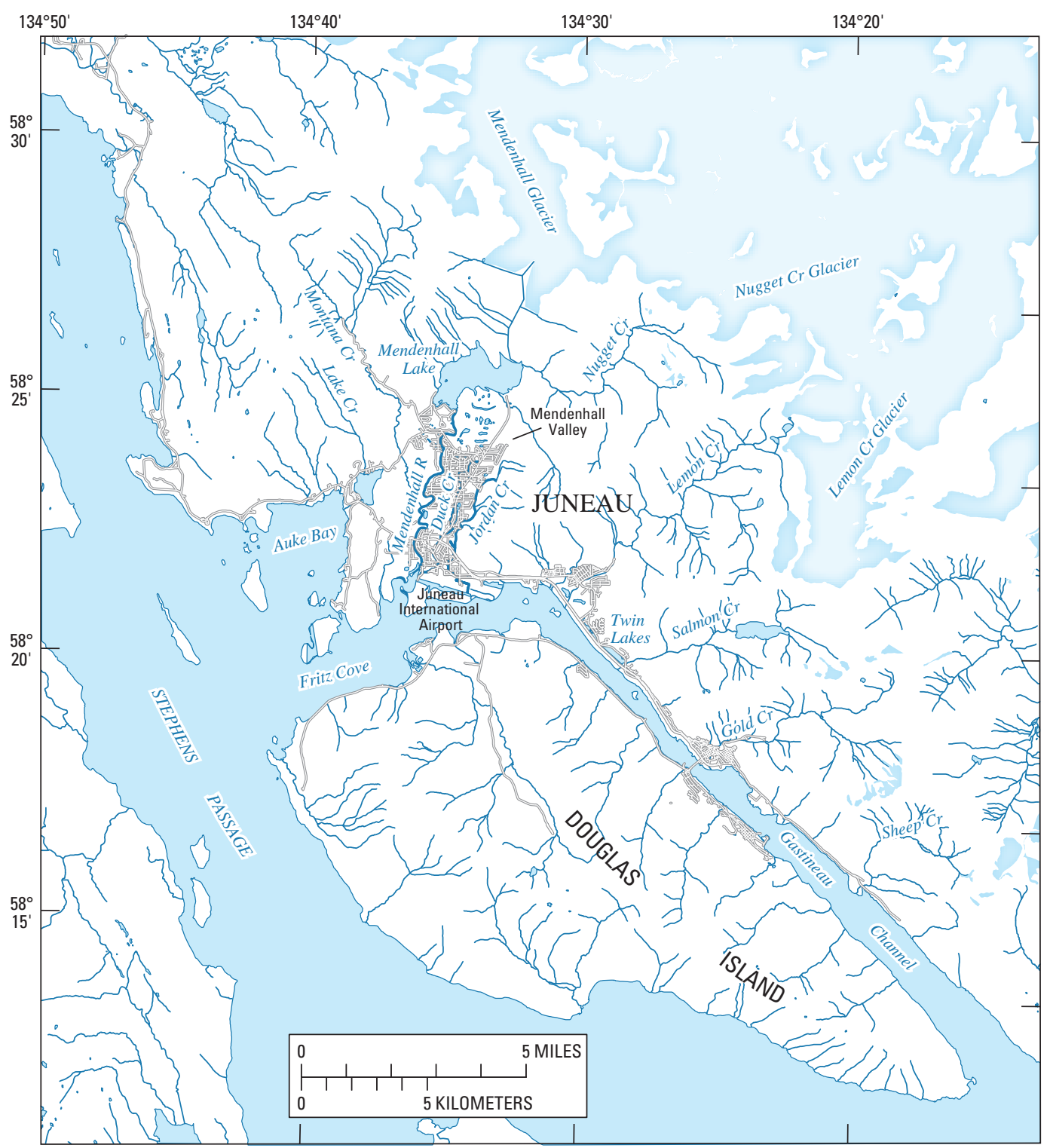

Base map data modified from U.S. Geological Survey, Census Bureau, University of Alaska, various scales. Projection: NAD_1983_StatePlane_Alaska_1_FIPS_5001_feet, North American Datum 1983

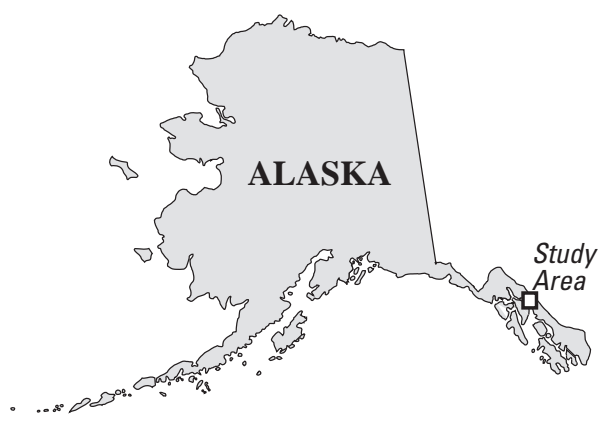

Figure 1. Location of Duck and Jordan Creeks, Juneau, Alaska. 


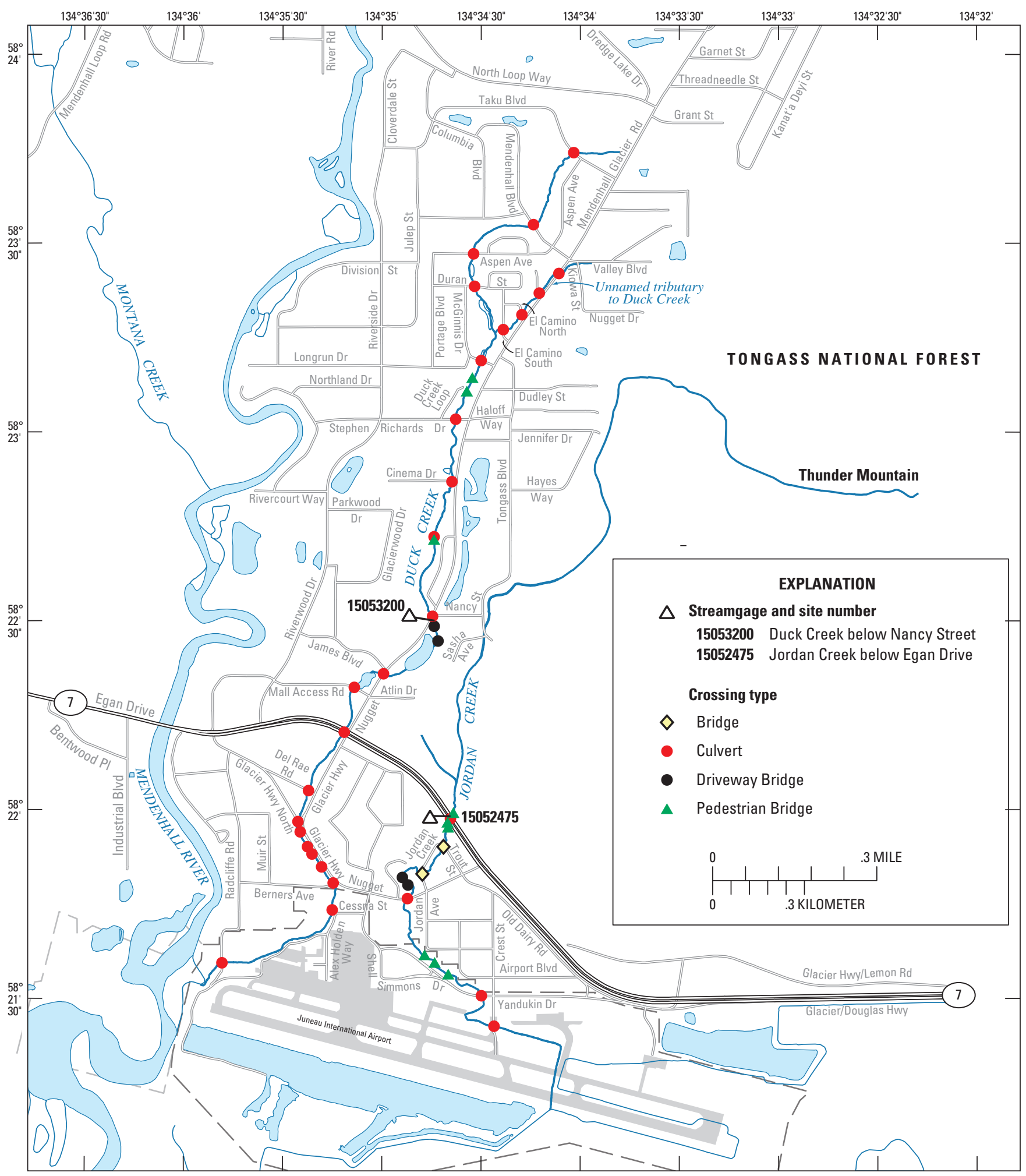

Base map data modified from U.S. Geological Survey, Census Bureau, University of Alaska,

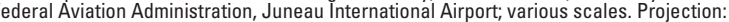
NAD_1983_StatePlane_Alaska_1_FIPS_5001_Feet, North American Datum 1983.

Figure 2. Location of stream-gaging stations, bridges, and culverts along Duck and Jordan Creeks, Juneau, Alaska. 


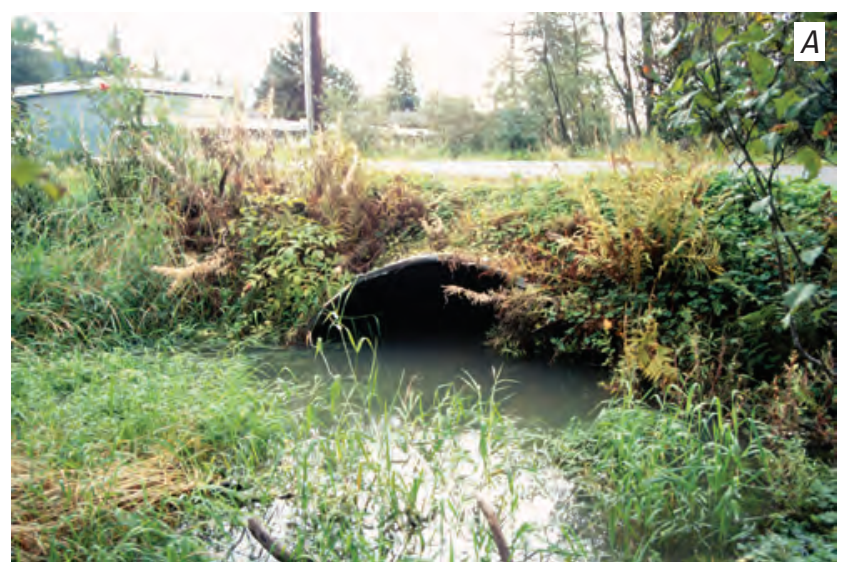

\section{Hydrology of Duck and Jordan Creeks}

Duck and Jordan Creeks receive water primarily from rainfall, and secondarily from snowmelt and ground water, depending on the season. Tides influence both streams near their mouths. The USGS systematically collected peakstreamflow data at continuously-operating stream-gaging stations on Duck Creek below Nancy Street (15053200) from 1994-2004 and on Jordan Creek below Egan Drive (15052475) from 1998-2005. The Jordan Creek streamflow record also includes a 1996 peak, considered a historic peak because it falls outside the systematic record. Daily mean discharge and annual maximum instantaneous peak streamflow data are available at http://waterdata.usgs.gov/

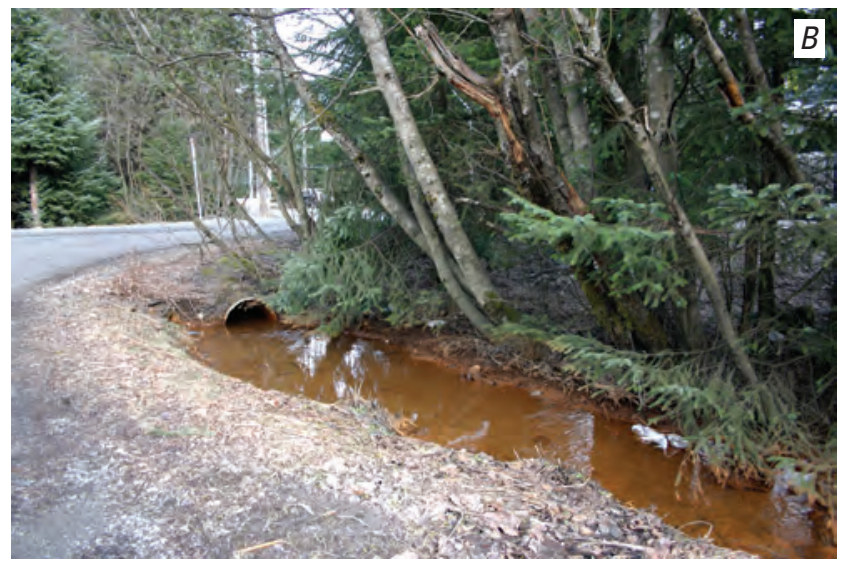
$\underline{\text { ak/nwis, }}$ or through the Alaska Science Center at the address listed at the back of this report. Annual peak streamflows are listed in table 1.

Table 1. Annual maximum instantaneous peak streamflow for Duck and Jordan Creeks, Juneau, Alaska.

[Abbreviations: USGS, U.S. Geological Survey; $\mathrm{ft}^{3} / \mathrm{s}$, cubic foot per second]

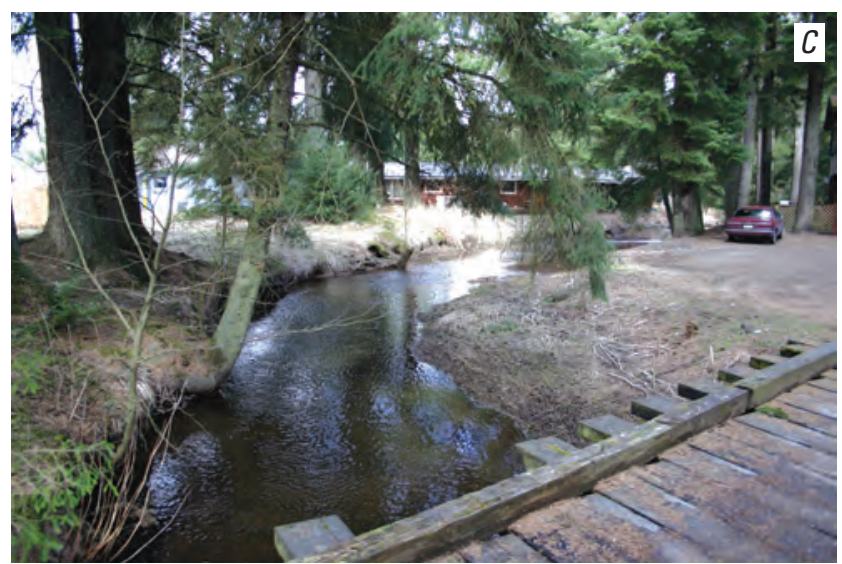

Figure 3. View of channel and structures along $(A)$ Duck Creek at a private driveway upstream from Berners Avenue, $(B)$ Unnamed Tributary to Duck Creek at North El Camino Street, and $(C)$ Jordan Creek at a private driveway downstream from Jordan Avenue, Juneau, Alaska.

\begin{tabular}{ccc}
\hline $\begin{array}{c}\text { USGS stream-gaging } \\
\text { station and number }\end{array}$ & Water year & $\begin{array}{c}\text { Annual maximum } \\
\text { instantaneous peak } \\
\text { streamflow (ft } \mathbf{3} / \mathbf{s})\end{array}$ \\
\hline Duck Creek below Nancy Street & 1994 & 38 \\
near Auke Bay (15053200) & 1995 & 41 \\
& 1996 & 49 \\
& 1997 & 26 \\
& 1998 & 25 \\
& 1999 & 48 \\
& 2000 & 180 \\
Jordan Creek below Egan Drive & 2001 & 34 \\
near Auke Bay (15052475) & 2002 & 27 \\
& 2003 & 35 \\
& 2004 & 27 \\
& 1996 & 2140 \\
& 1998 & 83 \\
& 2000 & 147 \\
& 2001 & 149 \\
& 2002 & 58 \\
& 2003 & 73 \\
& 2004 & 46 \\
& 2005 & 64 \\
\hline
\end{tabular}

\footnotetext{
${ }^{1}$ High outlier, but no adjustment possible because no historic period is available (Ed Neal, U.S. Geological Survey, oral commun., 2004).

${ }^{2}$ Historic peak, but no adjustment made because historic peak is less than systematic peaks.
} 
Duck Creek's streamflow correlates to ground water conditions (Neal, 2006) and rises and declines relatively slowly. Both of these conditions reflect its valley floor origin. In contrast, Jordan Creek has a steep, mountainous headwater and flashy—quickly rising and declining—-peak streamflows. Despite the urban nature of the watersheds, annual peakstreamflow data for Duck and Jordan Creeks show no readily discernible trends during their respective periods of record (fig. 4). The short systematic record of Jordan Creek peak streamflows appears to show a roughly declining trend, but a USGS miscellaneous measurement made in November 2005 (Ed Neal, USGS, written commun., 2006), shortly after the gaging station was discontinued, eliminates this appearance. The short period of record for both streams precludes the likelihood of identifying an urbanizing trend and the likelihood of comparing data from less- to moreurbanized areas. No known streamflow regulation affects peak streamflows in the study area.

For the period of record at the respective USGS streamgaging stations, peak streamflows for Duck Creek occurred from September to February, and peak streamflows for Jordan Creek occurred from late July to December. Average annual mean flow for Duck Creek is $4 \mathrm{ft}^{3} / \mathrm{s}$ and for Jordan Creek is $8 \mathrm{ft}^{3} / \mathrm{s}$. Records show zero-discharge days on both streams during dry periods, and observers reported seeing the channel bed dry.

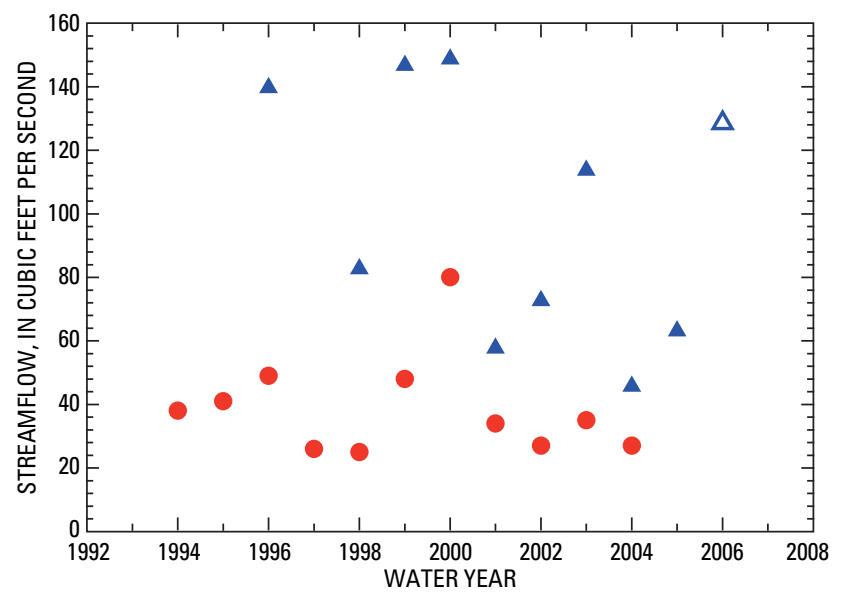

EXPLANATION

Maximum instantaneous peak streamflow

- Duck Creek below Nancy Street (15053200)

A Jordan Creek below Egan Drive (15052475)

Miscellaneous stramflow measurement

$\Delta$ Jordan Creek below Egan Drive (15052475)

Figure 4. Annual maximum instantaneous peak streamflow for Duck and Jordan Creeks, Juneau, Alaska.
In-channel ponding is common along both streams. In the study area, Duck Creek flows through small ponds at various locations upstream from Egan Drive, and Jordan Creek flows through several ponds downstream from Glacier Highway. This study did not investigate the extent of storage provided by these ponds during floods.

\section{Methods of Analysis}

This study updated the hydrologic analysis for Duck and Jordan Creeks by using streamflow data, a resource not available for the previous FIS. A log-Pearson type III analysis of the streamflow data, weighted with estimates from regional regression equations for southeast Alaska, provided peak streamflow estimates for various recurrence intervals. For the Duck Creek study reach, which is longer than the Jordan Creek study reach, streamflow estimates for locations upstream and downstream from the gaging station reflect changes in drainage area along the study reach.

Hydraulic analysis consisted of construction of a onedimensional, steady-state hydraulic model using results from the hydrologic analysis, channel geometry and engineered structures field surveys, LIDAR data interpretations, high-tide elevation, and the HEC-RAS modeling software. Modeling produced estimated water-surface profiles for floods with 10-, 50-, 100-, and 500-year recurrence intervals.

\section{Hydrologic Analysis}

Frequency analysis of a series of annual peak-streamflow data produces estimates of peak-streamflow frequency and magnitude, reported as T-year discharges. $\mathrm{T}$ is a recurrence interval, or the number of years during which the discharge is expected to be exceeded once, and is the reciprocal of the annual exceedance probability. For example, every year the 50 -year peak streamflow, or 50-year flood, has a 1 in 50, or 2 percent, chance of being exceeded. For Duck and Jordan Creeks, analysis of data from the USGS gaging station on each stream provided initial estimates of the peak-streamflow magnitude for the 2-, 5-, 10-, 25-, 50-, 100-, 200-, and 500year recurrence intervals (50-, 20-, 10-, 4-, 2-, 1-, 0.5-, and 0.2 -percent exceedance probabilities, respectively). Weighting these station-data-based estimates with regional equations developed for Alaska (Curran and others, 2003) provided final peak-streamflow estimates.

The USGS computer program PEAKFQ, available at http://water.usgs.gov/software/surface water.html, automates the log-Pearson Type III frequency distribution analysis recommended in the Interagency Advisory Committee on Water Data's Bulletin 17B (Interagency Advisory Committee 
on Water Data, 1982). PEAKFQ facilitated computation of station-data-based peak-streamflow magnitudes for Duck and Jordan Creeks. Systematic peak-streamflow records are available for the USGS gaging station on Duck Creek from 1994-2004 (11 years of record) and on Jordan Creek from 1998-2005 (8 years of record) (table 1). PEAKFQ identified the water year 2000 peak streamflow for Duck Creek as a high outlier, but no historic period could be determined so the frequency distribution was not adjusted. The 1996 historic peak for Jordan Creek was omitted from analysis because it was less than several systematic peaks (table 1). The generalized skew coefficient and standard error of the generalized skew for Streamflow Analysis Region 1 (Curran and others, 2003) were used for the PEAKFQ analysis. Peakstreamflow estimates computed from PEAKFQ are shown with 5- and 95-percent confidence limits in table 2.

Weighting the gaging-station-based peak-streamflow estimate with a regional-equation-based estimate can temper the uncertainties in streamflow estimates from gaging stations with short periods of record (Interagency Advisory Committee on Water Data, 1982). The Duck and Jordan Creek gaging stations have short periods of record that should statistically benefit from incorporating regional hydrology. The regional equations for southeast Alaska correlate peak streamflows to the basin characteristics drainage area, area of lakes and ponds (storage), mean annual precipitation, and mean minimum January temperature (Curran and others, 2003). Drainage area boundaries drawn on paper USGS topographic maps and digitized provided a digital determination of drainage area. Summing the areas of lake and pond polygons on digital hydrography coverages available at http://agdc.usgs.gov/data/ usgs/to geo.html and dividing by drainage area produced the percentage of lakes and ponds. Mean annual precipitation was computed from an Arc/Info AML application applied to the Arc/Info coverage of plate 2 of Jones and Fahl (1994) and mean minimum January temperature was visually estimated from plate 1 of Jones and Fahl (1994). Basin characteristics for Duck and Jordan Creeks (table 3) are similar, except Duck Creek's drainage area is about one-half as large as Jordan Creek's drainage area.

Table 2. Peak streamflow estimated from streamflow data and regional equations for selected recurrence intervals, Duck and Jordan Creeks, Juneau, Alaska.

[Abbreviaton: $\mathrm{ft}^{3} / \mathrm{s}$, cubic foot per second]

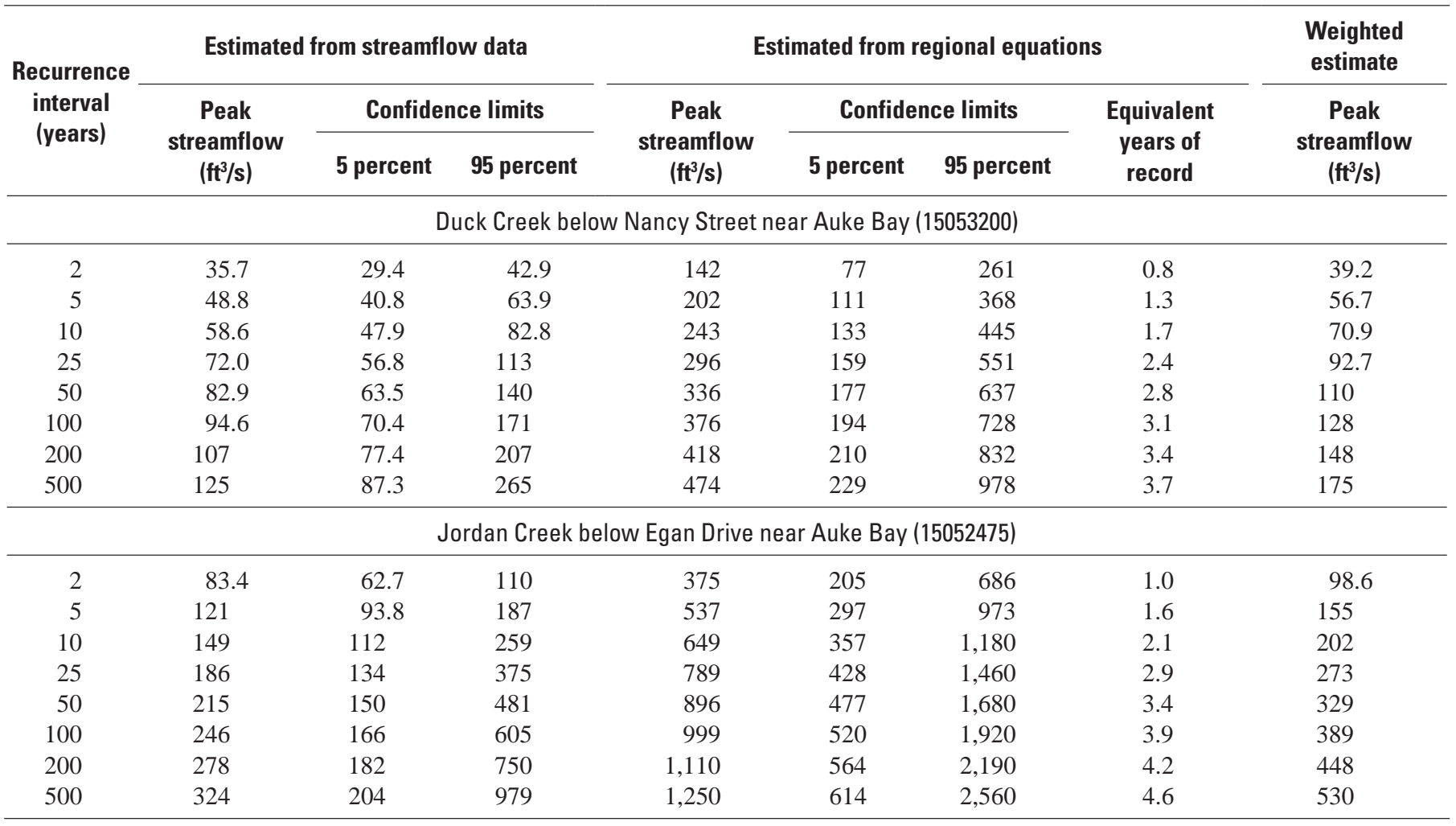


Table 3. Basin characteristics for Duck and Jordan Creeks, Juneau, Alaska.

[Abbreviations: $\mathrm{mi}^{2}$, square miles; in., inches]

\begin{tabular}{ccccc}
\hline Stream & $\begin{array}{c}\text { Drainage } \\
\text { area } \\
\left(\mathbf{m i}^{2}\right)\end{array}$ & $\begin{array}{c}\text { Area of lakes } \\
\text { and ponds } \\
\text { (storage) } \\
\text { (percent) }\end{array}$ & $\begin{array}{c}\text { Mean annual } \\
\text { precipitation } \\
\text { (in.) }\end{array}$ & $\begin{array}{c}\text { Mean } \\
\text { minimum } \\
\text { January } \\
\text { temperature } \\
\text { (degrees F) }\end{array}$ \\
\hline $\begin{array}{c}\text { Duck } \\
\text { Creek }\end{array}$ & 1.30 & 2 & 90 & 22 \\
$\begin{array}{c}\text { Jordan } \\
\text { Creek }\end{array}$ & 2.60 & 0 & 90 & 22 \\
\hline
\end{tabular}

The basin characteristics provided input variables for a USGS computer program developed for application of the regional regression equations (available at http://pubs.water. usgs.gov/wri034188). The program computed equation-based estimates of peak-streamflow magnitude and 5- and 95-percent confidence limits (table 2), as well as the equation's sitespecific equivalent years of record. Following procedures outlined in Curran and others (2003), the gaging-stationbased and equation-based estimates were weighted by the station's years of record and the equation's equivalent years of record, respectively. The final peak streamflow estimate for the selected recurrence intervals is this weighted estimate (table 2).

The weighted estimates of peak-streamflow magnitude for the 10-, 50-, 100-, and 500-year recurrence intervals at the gaging station provided inputs for the hydraulic analysis for all of Jordan Creek. Duck Creek is longer and includes two tributaries, and adjustments to the estimates to account for location within the watershed improved the simulated water-surface profile, particularly in the upper study reaches. Although procedures for estimating peak streamflow at ungaged locations on gaged streams are available (Curran and others, 2003), these require the use of the regional regression equation. The regional regression equation is not valid for drainage areas less than $0.72 \mathrm{mi}^{2}$ in this region. The upper reaches of Duck Creek are too small for the regression equations to be valid, so the estimates for the gaging station were adjusted by applying a ratio of the drainage areas of the desired location and the gaging station. Streamflow is not necessarily directly proportional to drainage area, but comparison to concurrent USGS miscellaneous measurements of streamflow at various locations along Duck Creek (table 4) shows drainage-area-weighted streamflows are reasonable.
Measured values were available only for streamflows on the order of the 2-year recurrence interval flood, requiring the assumption that the flow distribution throughout the watershed would be similar for larger floods. An arbitrary minimum of 10 percent of the streamflow in the adjacent main stem was assigned to the flow from the ponds upstream from Nancy Street, and to the unnamed tributary of the stream upstream from McGinnis Drive, because of the uncertainty inherent in the delineation of the drainage area boundaries. Final distribution of discharges to locations in the hydraulic model is shown in table 5.

Estimates provided for the 500-year peak streamflow should be interpreted cautiously. Record lengths for the Duck and Jordan Creek gaging stations, and for the gaging stations used to develop the regional equations, might not be long enough to support extrapolation to such long recurrence intervals (Curran and others, 2003). For critical applications, site-specific data such as paleoflood indicators might be advisable, although the recent post-glacial history of the Mendenhall Valley limits available flood records.

The discharges applied to the limits of the study area are consistently less than those in the previous FIS (table 5, assuming the upstream-most discharge published for the previous FIS is applied to the upstream study area limit). For example, the present estimate of the 100-year flood for Jordan Creek is 36 percent less than the previous value. These differences reflect changes in analysis methods and source data, particularly the introduction of streamflow data, rather than changes in hydrology.

\section{Hydraulic Analysis}

Water-surface profiles were computed for the study reaches using HEC-RAS version 3.1.3 (U.S. Army Corps of Engineers, 2002a, b, c). HEC-RAS is a one-dimensional modeling system that computes water-surface profiles for gradually varied flow by solving the one-dimensional energy equation and for rapidly varied flow (such as flow at hydraulic structures) by solving the momentum equation (U.S. Army Corps of Engineers, 2002a). The HEC-RAS modeling system can simulate unsteady flow; however, this study used only the steady flow capabilities. For this investigation, ponds along Duck and Jordan Creeks were arbitrarily assumed to have minimal storage capacity. Input parameters for steadyflow analysis in HEC-RAS include geometric and elevation data for the channel, culverts, bridges, and roads; roughness coefficients for the channel, overbank areas, and culverts; and flood discharge. 
Table 4. Measured streamflows and corresponding simulated streamflows using drainage-area ratios, Duck Creek, Juneau, Alaska.

[Measured streamflows: U.S. Geological Survey, written commun., 2005). Abbreviations: USGS, U.S. Geological Survey; ft³/s, cubic foot per second; -, not available]

\begin{tabular}{|c|c|c|c|c|c|c|}
\hline \multirow[b]{2}{*}{ Location } & \multicolumn{6}{|c|}{ Measured and simulated streamflows $\left(\mathrm{ft}^{3} / \mathrm{s}\right)$} \\
\hline & $\begin{array}{c}\text { Measured } \\
\text { 09-11-95 }\end{array}$ & Simulated & $\begin{array}{l}\text { Measured } \\
09-25-96\end{array}$ & Simulated & $\begin{array}{l}\text { Measured } \\
02-24-97\end{array}$ & Simulated \\
\hline Duck Creek at Taku Boulevard & 1.0 & 7.9 & 10.0 & 12.1 & 0.5 & 6.0 \\
\hline Duck Creek at Mendenhall Boulevard & 2.7 & 10.2 & - & 15.6 & 1.8 & 7.8 \\
\hline Duck Creek at Stephan Richards Drive & 14.6 & 14.3 & - & 21.8 & 4.5 & 10.9 \\
\hline Nancy Street Ponds at Nancy Street & - & 2.1 & - & 3.2 & - & 1.6 \\
\hline $\begin{array}{l}\text { Duck Creek upstream from confluence of tributary } \\
\text { near Nancy Street }\end{array}$ & - & 18.9 & - & 28.8 & - & 14.4 \\
\hline $\begin{array}{l}\text { Duck Creek downstream from confluence of } \\
\text { tributary near Nancy Steet (15053200) }\end{array}$ & - & 21.0 & - & 32.0 & - & 16.0 \\
\hline Duck Creek at Mall Access Road & - & 22.6 & - & 34.5 & - & 17.3 \\
\hline Duck Creek at Egan Drive & - & 23.4 & - & 35.6 & - & 17.8 \\
\hline Duck Creek at Del Rae Road & 22.5 & 24.1 & - & 36.7 & 21.4 & 18.3 \\
\hline \multirow{3}{*}{ Duck Creek at Berners Avenue } & 25.2 & 24.6 & 39.5 & 37.5 & 19.0 & 18.7 \\
\hline & \multicolumn{6}{|c|}{ Measured and simulated streamflows $\left(\mathrm{ft}^{3} / \mathrm{s}\right)$} \\
\hline & $\begin{array}{l}\text { Measured } \\
09-01-98\end{array}$ & Simulated & $\begin{array}{l}\text { Measured } \\
01-14-04\end{array}$ & Simulated & $\begin{array}{l}\text { Measured } \\
11-21-05\end{array}$ & Simulated \\
\hline Duck Creek at Taku Boulevard & - & 4.5 & - & 7.9 & - & 15.4 \\
\hline Duck Creek at Mendenhall Boulevard & - & 5.8 & - & 10.2 & 6.3 & 19.9 \\
\hline Duck Creek at Stephan Richards Drive & - & 8.2 & - & 14.3 & - & 27.9 \\
\hline Nancy Street Ponds at Nancy Street & 4.8 & 1.2 & - & 2.1 & - & 4.1 \\
\hline $\begin{array}{l}\text { Duck Creek upstream from confluence of tributary } \\
\text { near Nancy Street }\end{array}$ & 10.7 & 10.8 & - & 18.9 & - & 36.8 \\
\hline $\begin{array}{l}\text { Duck Creek downstream from confluence of } \\
\text { tributary near Nancy Steet (15053200) }\end{array}$ & - & 12.0 & - & 21.0 & 40.9 & 40.9 \\
\hline Duck Creek at Mall Access Road & - & 12.9 & 22.0 & 22.6 & - & 44.1 \\
\hline Duck Creek at Egan Drive & - & 13.4 & 23.9 & 23.4 & 41.6 & 45.5 \\
\hline Duck Creek at Del Rae Road & - & 13.7 & - & 24.1 & - & 46.9 \\
\hline Duck Creek at Berners Avenue & - & 14.1 & 24.4 & 24.6 & 45.6 & 47.9 \\
\hline
\end{tabular}


Table 5. Streamflows used for hydraulic model, Duck and Jordan Creeks, Juneau, Alaska.

[Streams and locations are shown in figure 6. Previous flood insurance study: from Federal Emergency Management Agency (1990); equivalent locations assigned. Abbreviations: USGS, U.S. Geological Survey; $\mathrm{ft}$, foot; $\mathrm{ft}^{3} / \mathrm{s}$, cubic foot per second; -, not appropriate]

\begin{tabular}{|c|c|c|c|c|c|c|c|c|c|c|}
\hline \multirow{2}{*}{ Stream and location } & \multirow{2}{*}{$\begin{array}{l}\text { River } \\
\text { station } \\
\text { (ft) }\end{array}$} & \multicolumn{5}{|c|}{ Current study } & \multicolumn{4}{|c|}{$\begin{array}{l}\text { Previous flood insurance study } \\
\text { Peak streamflow, for given } \\
\text { recurrence interval } \\
\left(\mathrm{ft}^{3} / \mathrm{s}\right)\end{array}$} \\
\hline & & 10-year & 50-year & 100-year & 500-year & $11-21-05$ & 10-year & 50-year & 100-year & 500-year \\
\hline \multicolumn{11}{|c|}{ Duck Creek } \\
\hline $\begin{array}{l}\text { Duck Creek upstream from Mendenhall } \\
\text { Boulevard }\end{array}$ & 16,755 & 34.5 & 53.5 & 62.3 & 85.2 & 19.9 & - & - & - & - \\
\hline $\begin{array}{l}\text { Duck Creek upstream from Duran } \\
\text { Street }\end{array}$ & 14,998 & 40.3 & 62.6 & 72.8 & 99.6 & 23.2 & - & - & - & - \\
\hline $\begin{array}{l}\text { Duck Creek upstream from Kodzoff } \\
\text { Acres }\end{array}$ & 10,398 & 61.4 & 95.3 & 111 & 152 & 35.4 & 51 & 62 & 67 & 78 \\
\hline $\begin{array}{l}\text { Duck Creek downstream from Nancy } \\
\text { Street at USGS gaging station } \\
(15053200)\end{array}$ & 8,858 & 70.9 & 110 & 128 & 175 & 40.9 & - & - & - & - \\
\hline $\begin{array}{l}\text { Duck Creek upstream from Mall } \\
\text { Access Road }\end{array}$ & 6,905 & 76.4 & 119 & 138 & 189 & 44.1 & 74 & 116 & 180 & 212 \\
\hline Inter-basin transfer from Duck Creek to & ${ }^{1} 5,606$ & & & & & & & & & \\
\hline Jordan Creek & ${ }^{2} 6,737$ & - & 6.0 & 21.7 & 62.3 & - & - & - & - & - \\
\hline
\end{tabular}

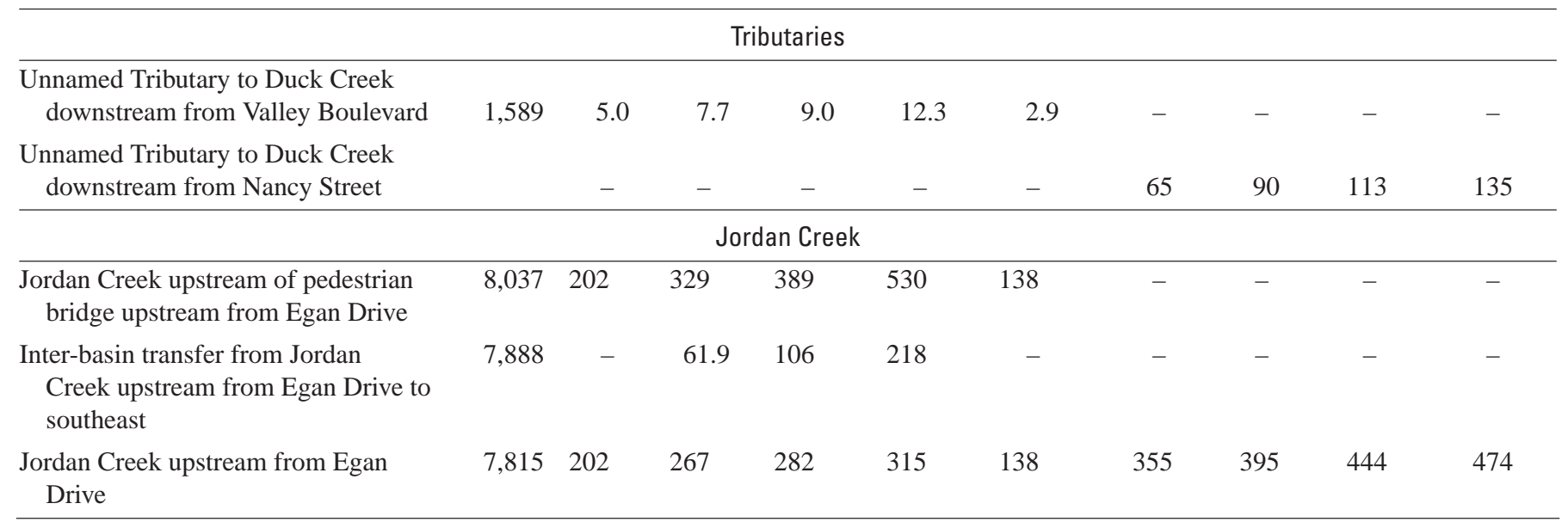

${ }^{1}$ On Duck Creek.

${ }^{2}$ On Jordan Creek. 


\section{Stream Network}

The initial basis for defining the stream network was a GIS-based hydrology coverage provided by the City and Borough of Juneau. The network for this study consists of the main stems of Duck and Jordan Creeks, plus a small unnamed tributary to Duck Creek upstream from McGinnis Drive. A final stream center line coverage for the study area was generated from this hydrology coverage, survey data for this study, and LIDAR data provided by the City and Borough of Juneau (fig. 5). The primary purpose of these stream center lines was to compute data such as reach lengths for the model, necessitating straight paths through the centers of the numerous ponds along both streams. Thus, the stream center lines are not a precise representation of the streams' location and morphology.

Further simplification of the stream network was useful to simulate flow leaving the main stem of Duck and Jordan Creeks. Inter-basin flow from Jordan Creek to the southeast at Egan Drive and from Duck Creek to Jordan Creek downstream from Egan Drive was simulated as lateral weirs.

\section{Field Survey of Cross Sections and Hydraulic Structures}

The surveying method for cross sections and hydraulic structures included a combination of Global Positioning System (GPS) and conventional survey techniques. Baselines were created from static GPS data collected at local benchmarks and data from National Geodetic Survey (NGS) Continuously Operating Reference Stations (CORS) sites, then processed and used in a network adjustment to obtain latitude, longitude, and ellipsoid heights. Selected benchmarks with published elevations provided constraints on the GEOID99 geoid model, which then was used to obtain elevations relative to Mean Lower Low Water, a commonly used local vertical datum. Using this local geoid model and the constrained coordinates for the benchmarks, temporary benchmarks (appendix A) were established throughout the study area using GPS Real-Time Kinetic (RTK) techniques. These reference marks became hubs and backsights for a conventional survey of most cross sections and miscellaneous points.

Static and RTK GPS data were collected using Trimble 4700 receivers with a microcentered L1/L2 antenna with a ground plane antenna. Selected NGS, Alaska Department of Transportation and Public Facilities (AKDOTPF), and USGS benchmarks provided pre-surveyed locations for base stations. Published horizontal coordinates for four base stations (lev1, ais1, JUN.TIDAL.GPS, and gus2) provided constraints for network adjustment. Horizontal coordinates for this project are referenced to the NAD83 (CORS96) epoch 2003 datum. A 2002 AKDOTPF leveling survey (Tim Reed, Alaska Department of Transportation and Public Facilities, written commun., 2004) and NGS (http://www.ngs.noaa. gov) provided elevations (orthometric heights) for four base stations (JUN.TIDAL.GPS, EDDIE, 95J16, and UW8043) used to constrain the GEOID99 model. Wild T1600 and Wild T1610 total stations and a Trimble datalogger were used for conventional surveying tasks.

Between August 2004 and June 2005, the USGS surveyed 146 cross sections at 25 culverts and 5 bridges on Duck Creek, and 60 cross sections at 4 culverts and 10 bridges on Jordan Creek (fig. 6A-F). Two cross sections were added at the study margins, one a duplicate of survey data and one from LIDAR data. Map identification numbers are crossreferenced to survey identifiers (used as node descriptions in the hydraulic model) in table 6 and to letter identifiers given to selected cross sections. Typically, surveys included two cross sections upstream and two downstream from each hydraulic structure to help model the hydraulic effect of the structure, and one or two cross sections between hydraulic structures to characterize the typical channel geometry. Data for culvert dimensions, materials, and other physical characteristics were collected with measuring tapes and visual observations. This study does not include culverts replaced since 2004 .

The absolute error in surveyed points, or difference from actual elevation, depends on the absolute error in the GPS network and RTK GPS survey and the relative error in the conventional survey. The absolute error in the GPS network is less than $0.03 \mathrm{ft}$ for the study area. The absolute error in the RTK survey was not determined directly for this study, but is estimated to be less than $0.1 \mathrm{ft}$ based on the equipment and procedures used (Trimble, 1999). The relative error for the conventionally surveyed points, or difference from the elevation relative to the hubs, is less than $0.1 \mathrm{ft}$. The absolute error for the survey is the sum of these errors rounded to one significant figure, or less than $0.2 \mathrm{ft}$.

GPS and conventional survey data were processed using Trimble Geomatics Office software (Trimble, 1999). Final horizontal and vertical coordinates and elevations (appendix B) were transformed to station and elevation data for cross sections using a customized macro in a Microsoft Excel ${ }^{\circledR}$ spreadsheet. This macro allows selection of two survey points for alignment of the cross section, and then projects all other points onto this alignment to provide a true channel distance along the alignment. 


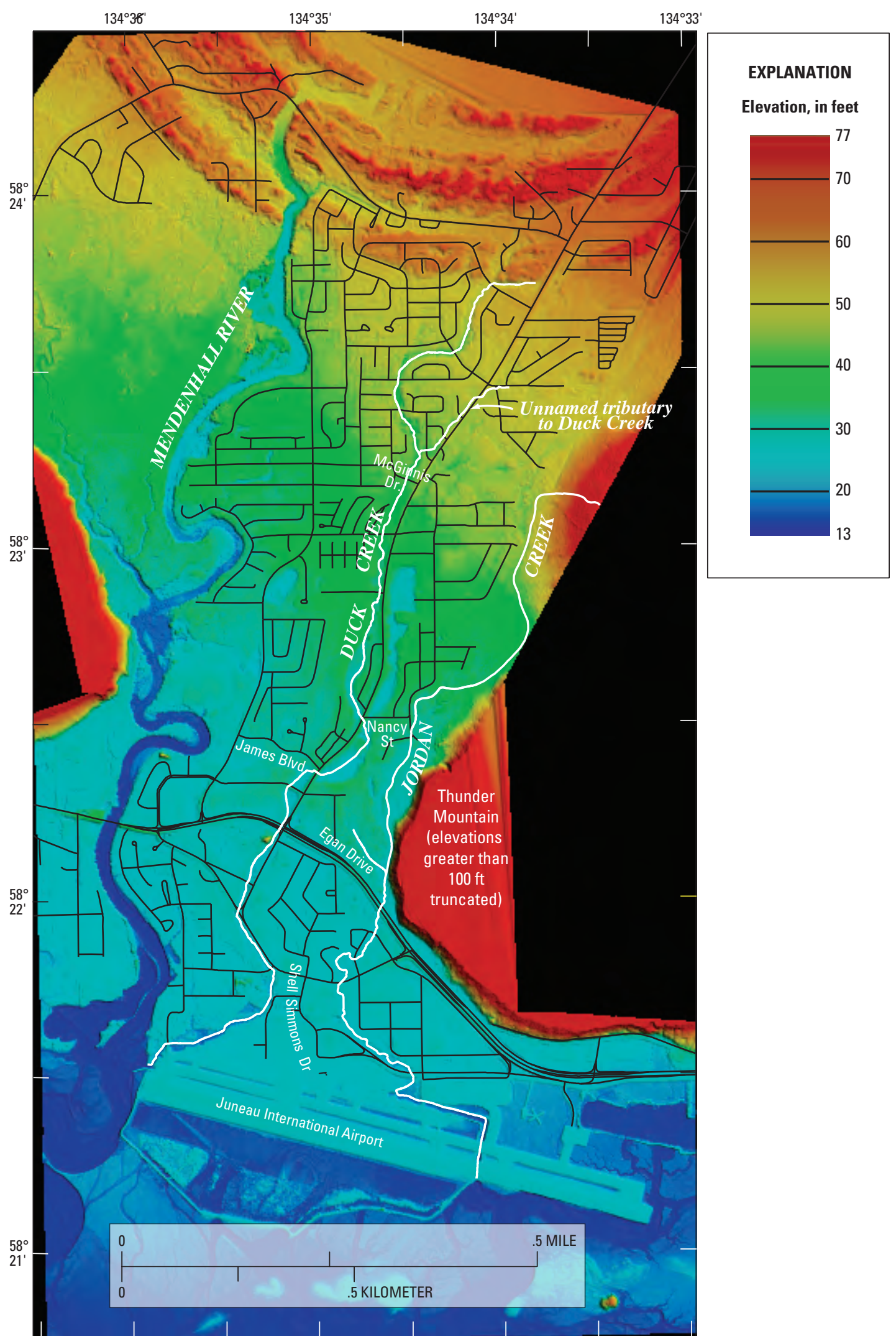

Base map data modified from U.S. Geological Survey, Census Bureau, University of Alaska; various scales. LIDAR data (2002) from City and Borough of Juneau, AK. Projection:

Figure 5. Modeled stream center lines and general elevation data for Duck and Jordan Creeks, Juneau, Alaska. 
A.

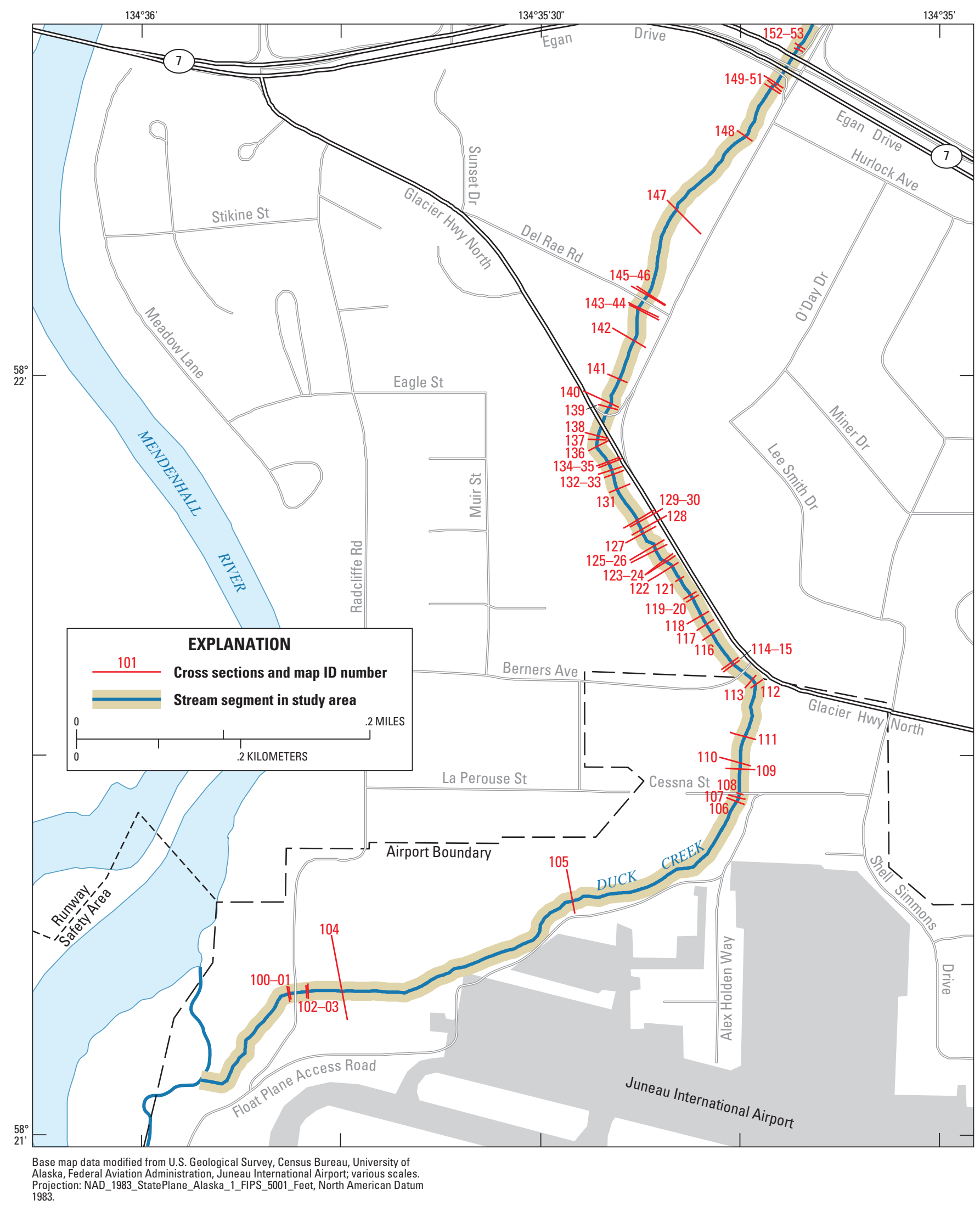

Figure 6. Locations of modeled and surveyed cross sections along $(A-D)$ Duck Creek and (E-F) Jordan Creek, Juneau, Alaska. 
B.

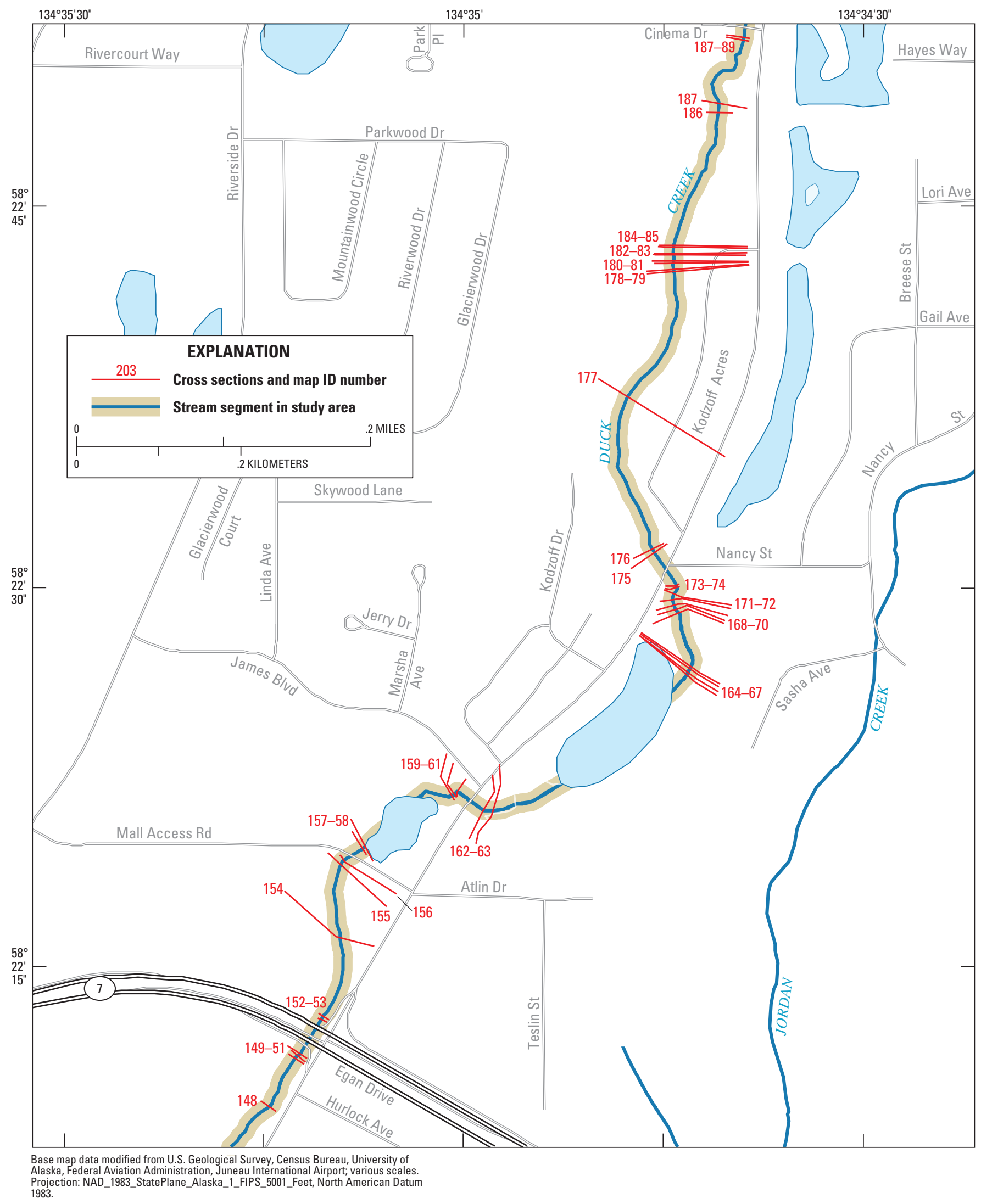

Figure 6.-Continued 
c.

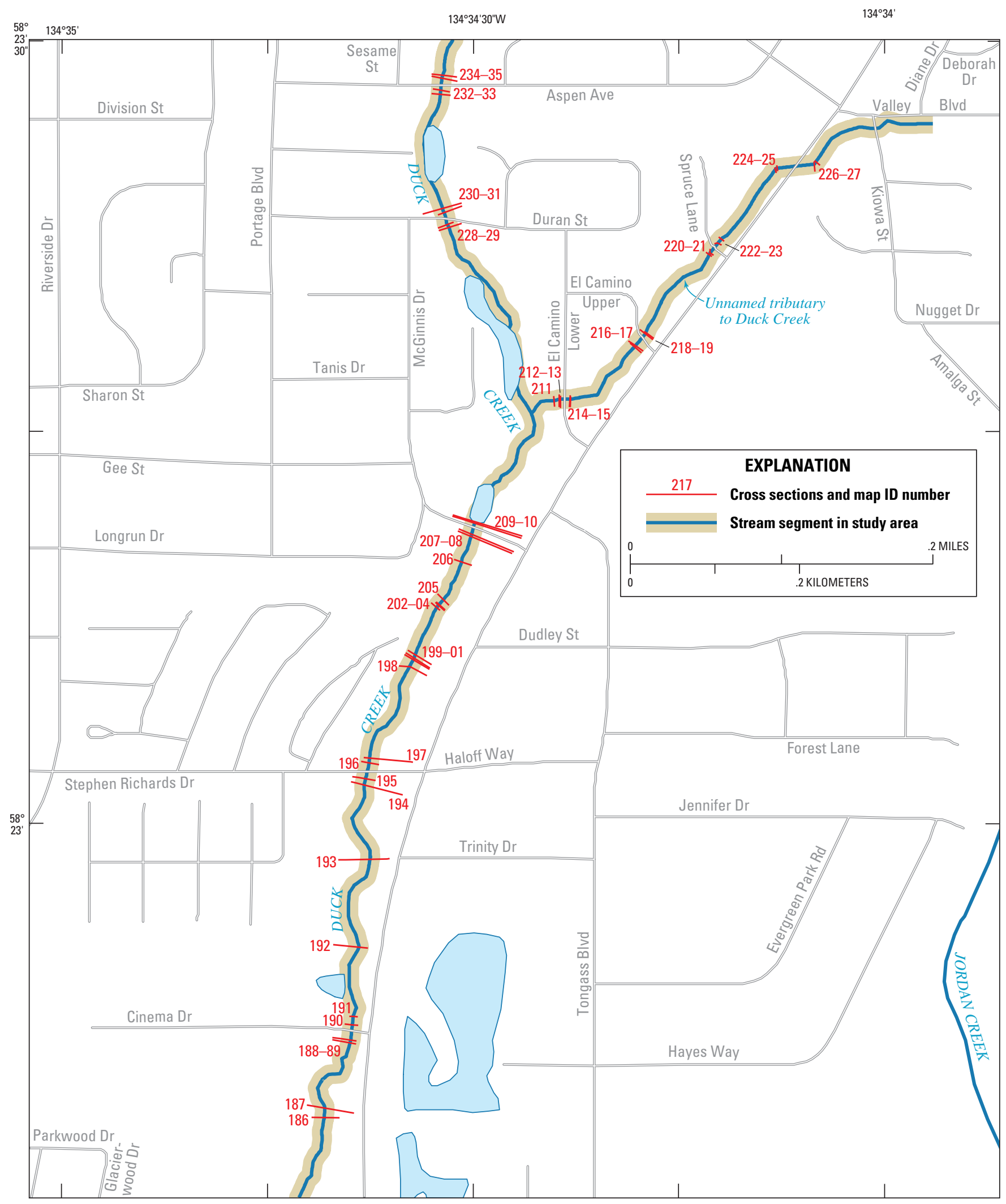

Base map data modified from U.S. Geological Survey, Census Bureau, University of

Alaska, Federal Aviation Administration, Juneau International Airport; various scales.

1983.

Figure 6.-Continued 
D.

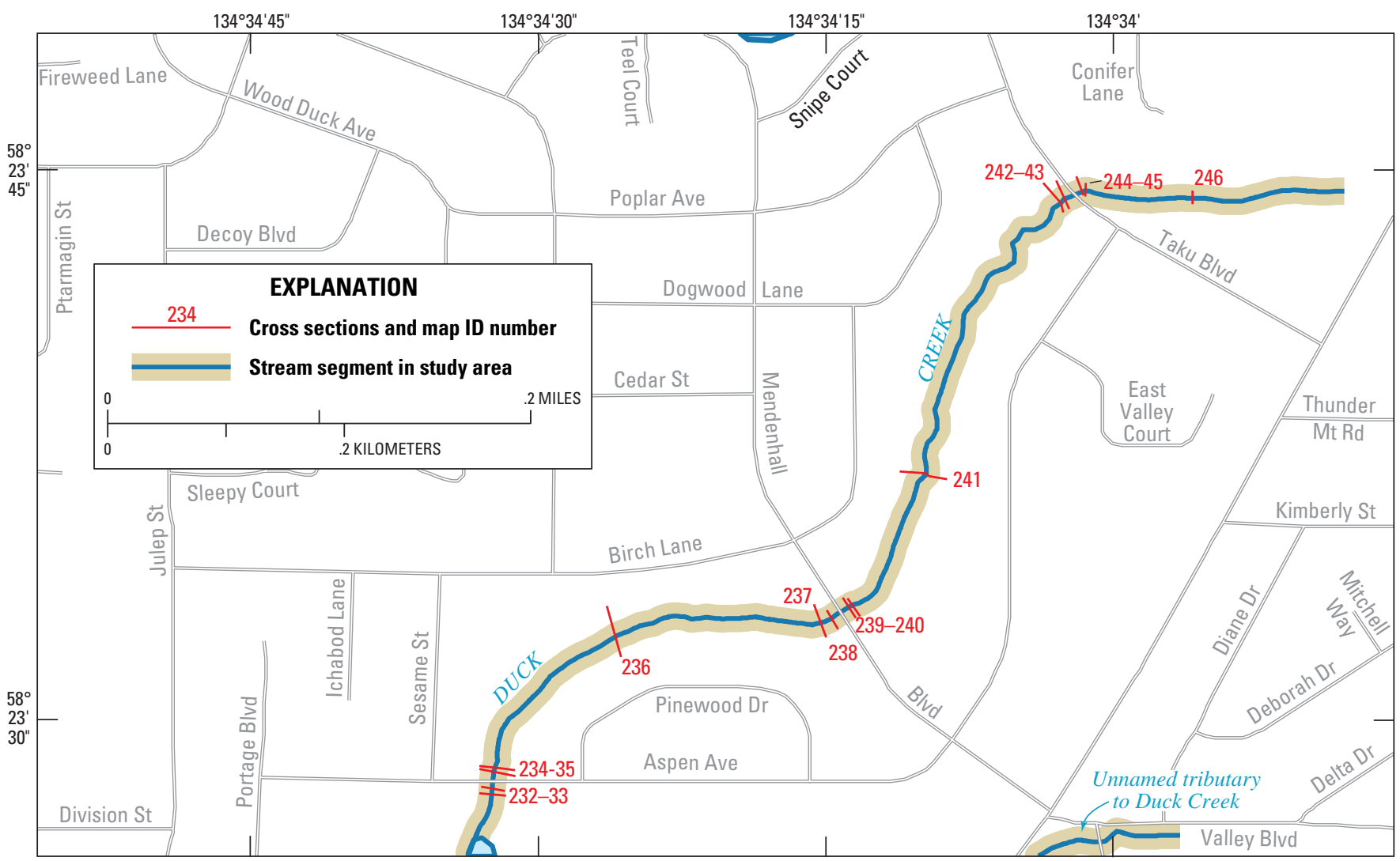

Base map data modified from U.S. Geological Survey, Census Bureau, University of Alaska, Federal Aviation Administration, Juneau International Airport; various scales. Projection. NAD_1983_StatePlane_Alaska___FP_500__eet, North American Datum

Figure 6.-Continued 
E.

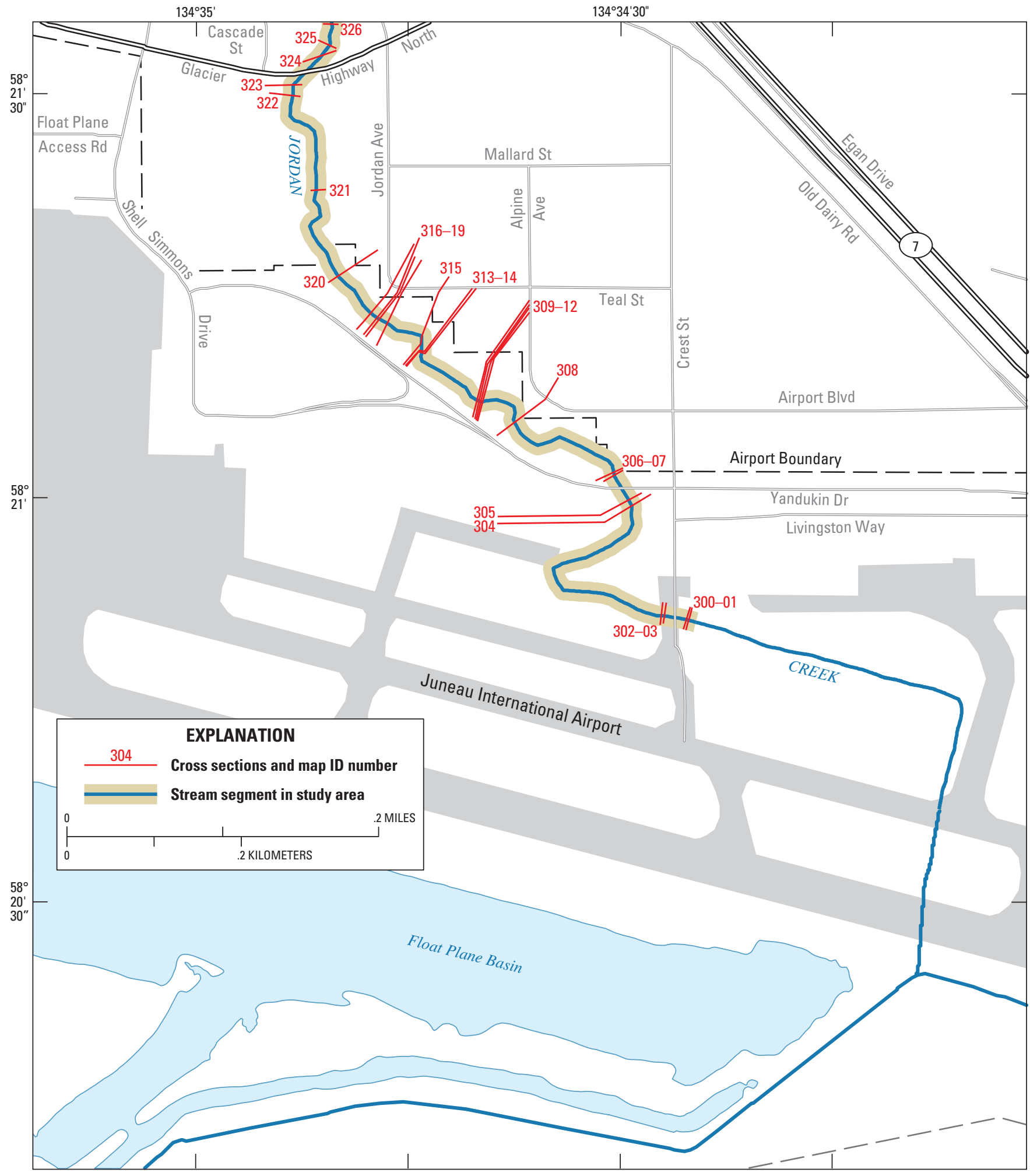

Base map data modified from U.S. Geological Survey, Census Bureau, University of

Alaska, Federal Aviation Administration, Juneau International Airport; various scales.

Projection: NAD_1983_StatePlane_Alaska_1_FIPS_5001_Feet, North American Datum

1983

Figure 6.-Continued 
F.

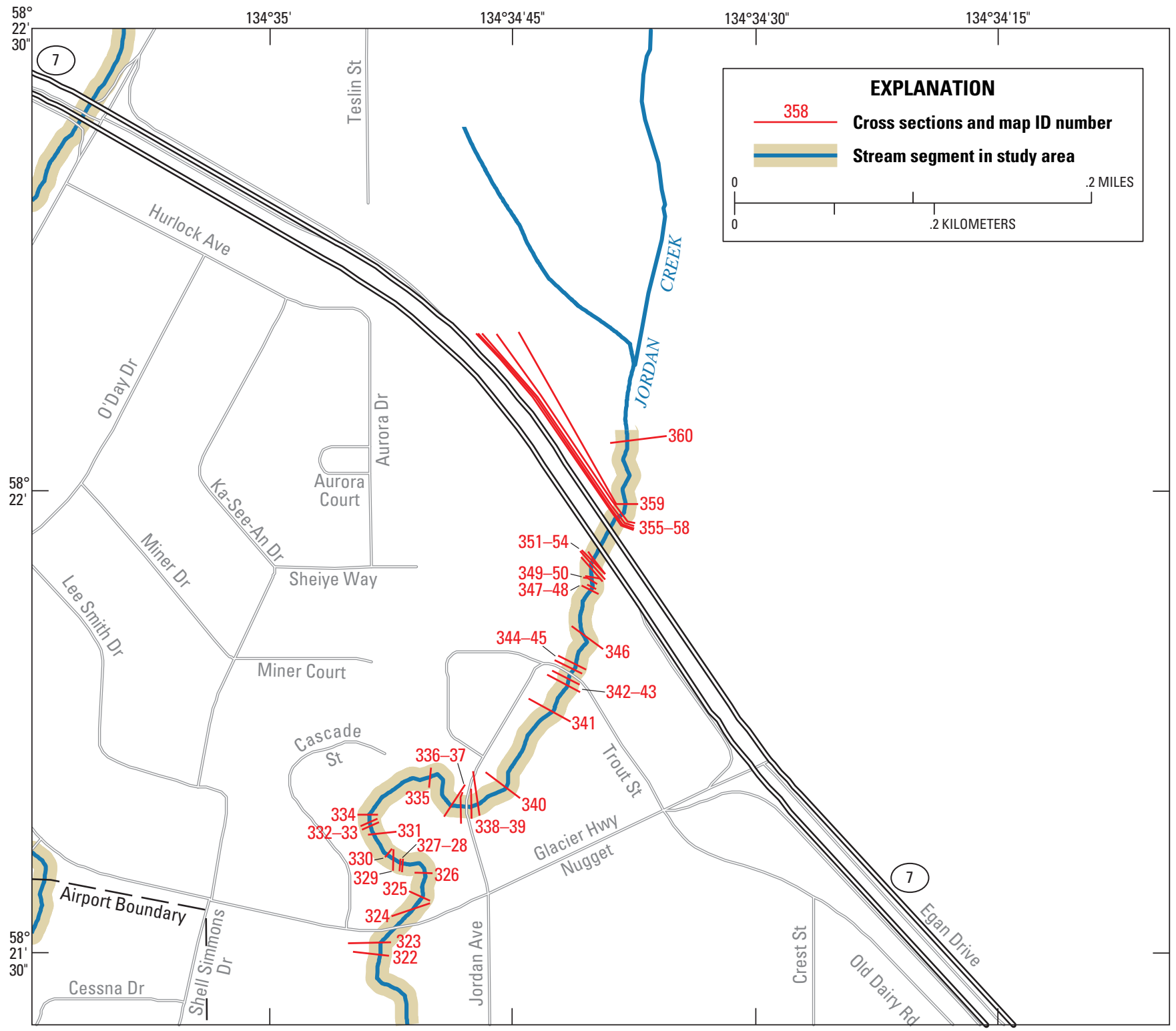

Base map data modified from U.S. Geological Survey, Census Bureau, University of

Alaska, Federal Aviation Administration, Juneau International Airport; various scales.

1983.

Figure 6.-Continued 
Table 6. Index to cross section identifiers, Duck and Jordan Creeks, Juneau, Alaska.

$\begin{array}{ccc}\text { Map } & \text { Survey and } & \text { Letter } \\ \text { identifier } & \text { model identifier } & \text { identifier }\end{array}$

Lower Duck Creek main stem

$\begin{array}{lll}100 & \text { D.RC.XS1 } & \text { A } \\ 101 & \text { D.RC.XS2 } & \text { B } \\ 102 & \text { D.RC.XS3 } & \text { C } \\ 103 & \text { D.RC.XS4 } & \\ 104 & \text { D.RC.XS30 } & \text { D } \\ 105 & \text { D.RC.XS50 } & \text { E } \\ 106 & \text { D.CS.XS1 } & \text { F } \\ 107 & \text { D.CS.XS2 } & \\ 108 & \text { D.CS.XS2-5 } & \text { G }\end{array}$

109

110

111

112

113

114

115

116

117

118

119

120

121

122

123

124

125

126

127

128

129

130

131

132

133

134

135

136

137

138

139

140

141

142

143

144

145

146

147

148

149

150
$\mathrm{S} 2-5$

D.CS.XS3

D.CS.XS50

D.BN.XS1

D.BN.XS2

D.BN.XS3

D.BN.XS4

D.BN.XS50

D.PP.XS1

D.PP.XS2

D.PP.XS3

D.PP.XS4

D.PP.XS50

D.BB.XS1

D.BB.XS1-5

D.BB.XS2

D.BB.XS3

D.BB.XS4

D.VP.XS1

D.VP.XS2

D.VP.XS3

D.VP.XS4

D.VP.XS50

D.FA.XS1

D.FA.XS2

D.FA.XS3

D.FA.XS4

D.FA.XS50

D.GH.XS1

D.GH.XS2

D.GH.XS4

D.GH.XS40

D.GH.XS60

D.DR.XS1

D.DR.XS2

D.DR.XS3

D.DR.XS4

D.DR.XS40

D.DR.XS60

D.EG.XS0

D.EG.XS1
D.CS.XS4

D.GH.XS3

\begin{tabular}{|c|c|c|}
\hline $\begin{array}{c}\text { Map } \\
\text { identifier }\end{array}$ & $\begin{array}{c}\text { Survey and } \\
\text { model identifier }\end{array}$ & $\begin{array}{c}\text { Letter } \\
\text { identifier }\end{array}$ \\
\hline \multicolumn{3}{|c|}{ Lower Duck Creek main stem-Continued } \\
\hline 151 & D.EG.XS2 & $\mathrm{AB}$ \\
\hline 152 & D.EG.XS3 & \\
\hline 153 & D.EG.XS4 & $\mathrm{AC}$ \\
\hline 154 & D.EG.XS50 & $\mathrm{AD}$ \\
\hline 155 & D.MA.XS1 & $\mathrm{AE}$ \\
\hline 156 & D.MA.XS2 & $\mathrm{AF}$ \\
\hline 157 & D.MA.XS3 & \\
\hline 158 & D.MA.XS4 & AG \\
\hline 159 & D.MJ.XS0 & \\
\hline 160 & D.MJ.XS1 & $\mathrm{AH}$ \\
\hline 161 & D.MJ.XS2 & \\
\hline 162 & D.MJ.XS3 & AI \\
\hline 163 & D.MJ.XS4 & $\mathrm{AJ}$ \\
\hline 164 & D.MJBR1.XS1 & $\mathrm{AK}$ \\
\hline 165 & D.MJBR1.XS2 & \\
\hline 166 & D.MJBR1.XS3 & $\mathrm{AL}$ \\
\hline 167 & D.MJBR1.XS4 & \\
\hline 168 & D.MJBR2.XS1 & $\mathrm{AM}$ \\
\hline 169 & D.MJBR2.XS2 & \\
\hline 170 & D.MJBR2.XS3 & $\mathrm{AN}$ \\
\hline 171 & D.MJBR2.XS4 & $\mathrm{AO}$ \\
\hline 172 & D.MJBR2.XS50 & \\
\hline 173 & D.MN.XS1 & AP \\
\hline 174 & D.MN.XS2 & \\
\hline 175 & D.MN.XS3 & AQ \\
\hline 176 & D.MN.XS4 & $\mathrm{AR}$ \\
\hline 177 & D.MN.XS30 & AS \\
\hline 178 & D.KA1.XS1 & AT \\
\hline 179 & D.KA1.XS2 & \\
\hline 180 & D.KA1.XS3 & $\mathrm{AU}$ \\
\hline 181 & D.KA1.XS4 & \\
\hline 182 & D.KA2.XS1 & AV \\
\hline 183 & D.KA2.XS2 & \\
\hline 184 & D.KA2.XS3 & AW \\
\hline 185 & D.KA2.XS4 & $\mathrm{AX}$ \\
\hline 186 & D.KA2.XS50-5 & $\mathrm{AY}$ \\
\hline 187 & D.KA2.XS50 & $\mathrm{AZ}$ \\
\hline 188 & D.CI.XS1 & BA \\
\hline 189 & D.CI.XS2 & \\
\hline 190 & D.CI.XS3 & BB \\
\hline 191 & D.CI.XS4 & \\
\hline 192 & D.CI.XS40 & $\mathrm{BC}$ \\
\hline 193 & D.CI.XS60 & $\mathrm{BD}$ \\
\hline 194 & D.SR.XS1 & \\
\hline 195 & D.SR.XS2 & $\mathrm{BE}$ \\
\hline 196 & D.SR.XS3 & \\
\hline 197 & D.SR.XS4 & $\mathrm{BF}$ \\
\hline 198 & D.SRPB1.XS1 & \\
\hline 199 & D.SRPB1.XS2 & \\
\hline 200 & D.SRPB1.XS3 & BG \\
\hline 201 & D.SRPB1.XS4 & \\
\hline
\end{tabular}

\begin{tabular}{|c|c|c|}
\hline $\begin{array}{c}\text { Map } \\
\text { identifier }\end{array}$ & $\begin{array}{c}\text { Survey and } \\
\text { model identifier }\end{array}$ & $\begin{array}{c}\text { Letter } \\
\text { identifier }\end{array}$ \\
\hline \multicolumn{3}{|c|}{ Lower Duck Creek main stem-Continued } \\
\hline 202 & D.SRPB2.XS1 & $\mathrm{BH}$ \\
\hline 203 & D.SRPB2.XS2 & \\
\hline 204 & D.SRPB2.XS3 & BI \\
\hline 205 & D.SRPB2.XS4 & BJ \\
\hline 206 & D.SRPB2.XS50 & \\
\hline 207 & D.MG.XS1 & $\mathrm{BK}$ \\
\hline 208 & D.MG.XS2 & \\
\hline 209 & D.MG.XS3 & BL \\
\hline 210 & D.MG.XS4 & $\mathrm{BM}$ \\
\hline \multicolumn{3}{|c|}{ Unnamed Tributary to Duck Creek } \\
\hline 211 & D.ES.XS0 & A \\
\hline 212 & D.ES.XS1 & $\mathrm{B}$ \\
\hline 213 & D.ES.XS2 & \\
\hline 214 & D.ES.XS3 & \\
\hline 215 & D.ES.XS4 & $\mathrm{C}$ \\
\hline 216 & D.EN.XS1 & $\mathrm{D}$ \\
\hline 217 & D.EN.XS2 & \\
\hline 218 & D.EN.XS3 & \\
\hline 219 & D.EN.XS4 & $\mathrm{E}$ \\
\hline 220 & D.SP.XS1 & $\mathrm{F}$ \\
\hline 221 & D.SP.XS2 & \\
\hline 222 & D.SP.XS3 & \\
\hline 223 & D.SP.XS4 & G \\
\hline 224 & D.VB.XS1 & $\mathrm{H}$ \\
\hline 225 & D.VB.XS2 & \\
\hline 226 & D.VB.XS3 & \\
\hline 227 & D.VB.XS4 & I \\
\hline \multicolumn{3}{|c|}{ Upper Duck Creek main stem } \\
\hline 228 & D.DU.XS1 & $\mathrm{BN}$ \\
\hline 229 & D.DU.XS2 & $\mathrm{BO}$ \\
\hline 230 & D.DU.XS3 & BP \\
\hline 231 & D.DU.XS4 & BQ \\
\hline 232 & D.AS.XS1 & \\
\hline 233 & D.AS.XS2 & $\mathrm{BR}$ \\
\hline 234 & D.AS.XS3 & BS \\
\hline 235 & D.AS.XS4 & \\
\hline 236 & D.AS.XS50 & BT \\
\hline 237 & D.MB.XS1 & BU \\
\hline 238 & D.MB.XS2 & \\
\hline 239 & D.MB.XS3 & $\mathrm{BV}$ \\
\hline 240 & D.MB.XS4 & \\
\hline 241 & D.MB.XS50 & BW \\
\hline 242 & D.TK.XS1 & $\mathrm{BX}$ \\
\hline 243 & D.TK.XS2 & \\
\hline 244 & D.TK.XS3 & BY \\
\hline 245 & D.TK.XS4 & BZ \\
\hline 246 & \multicolumn{2}{|c|}{$\begin{array}{l}\text { Copy of D.TK.XS4, used } \\
\text { to extend model to match } \\
\text { previous study }\end{array}$} \\
\hline
\end{tabular}


Table 6. Index to cross section identifiers, Duck and Jordan Creeks, Juneau, Alaska.-Continued

\begin{tabular}{|c|c|c|c|c|c|c|c|c|}
\hline $\begin{array}{l}\text { Map } \\
\text { identifier }\end{array}$ & $\begin{array}{c}\text { Survey and } \\
\text { model identifier }\end{array}$ & $\begin{array}{c}\text { Letter } \\
\text { identifier }\end{array}$ & $\begin{array}{c}\text { Map } \\
\text { identifier }\end{array}$ & $\begin{array}{c}\text { Survey and } \\
\text { model identifier }\end{array}$ & $\begin{array}{c}\text { Letter } \\
\text { identifier }\end{array}$ & $\begin{array}{c}\text { Map } \\
\text { identifier }\end{array}$ & $\begin{array}{c}\text { Survey and } \\
\text { model identifier }\end{array}$ & $\begin{array}{l}\text { Letter } \\
\text { identifier }\end{array}$ \\
\hline \multicolumn{3}{|c|}{ Jordan Creek } & \multicolumn{3}{|c|}{ Jordan Creek—Continued } & \multicolumn{3}{|c|}{ Jordan Creek—Continued } \\
\hline 300 & J.CS.XS1 & A & 321 & J.YDPB3.XS60 & $\mathrm{K}$ & 342 & J.TR.XS1 & $\mathrm{V}$ \\
\hline 301 & J.CS.XS2 & & 322 & J.GH.XS1 & $\mathrm{L}$ & 343 & J.TR.XS2 & \\
\hline 302 & J.CS.XS3 & B & 323 & J.GH.XS2 & M & 344 & J.TR.XS3 & \\
\hline 303 & J.CS.XS4 & & 324 & J.GH.XS3 & $\mathrm{N}$ & 345 & J.TR.XS4 & $\mathrm{W}$ \\
\hline 304 & J.YD.XS1 & & 325 & J.GH.XS4 & & 346 & J.TR.XS50 & \\
\hline 305 & J.YD.XS2 & $\mathrm{C}$ & 326 & J.GH.XS50 & & 347 & J.TRPB1.XS1 & $\mathrm{X}$ \\
\hline 306 & J.YD.XS3 & & 327 & J.GHPB1.XS1 & & 348 & J.TRPB1.XS2 & \\
\hline 307 & J.YD.XS4 & $\mathrm{D}$ & 328 & J.GHPB1.XS2 & $\mathrm{O}$ & 349 & J.TRPB1.XS3 & \\
\hline 308 & J.YD.XS50 & & 329 & J.GHPB1.XS3 & $\mathrm{P}$ & 350 & J.TRPB2.XS1 & \\
\hline 309 & J.YDPB1.XS1 & E & 330 & J.GHPB1.XS4 & & 351 & J.TRPB2.XS2 & $\mathrm{Y}$ \\
\hline 310 & J.YDPB1.XS2 & & 331 & J.GHPB2.XS1 & $\mathrm{Q}$ & 352 & J.TRPB2.XS3 & \\
\hline 311 & J.YDPB1.XS3 & & 332 & J.GHPB2.XS2 & & 353 & J.EG.XS1 & \\
\hline 312 & J.YDPB1.XS4 & $\mathrm{F}$ & 333 & J.GHPB2.XS3 & & 354 & J.EG.XS2 & Z \\
\hline 313 & J.YDPB2.XS2 & G & 334 & J.GHPB2.XS4 & $\mathrm{R}$ & 355 & J.EG.XS3 & AA \\
\hline 314 & J.YDPB2.XS3 & & 335 & J.GHPB2.XS50 & & 356 & J.EG.XS4 & $\mathrm{AB}$ \\
\hline 315 & J.YDPB2.XS4 & $\mathrm{H}$ & 336 & J.JA.XS1 & $\mathrm{S}$ & 357 & J.EGPB1.XS2 & \\
\hline 316 & J.YDPB3.XS1 & I & 337 & J.JA.XS2 & & 358 & J.EGPB1.XS3 & \\
\hline 317 & J.YDPB3.XS2 & & 338 & J.JA.XS3 & & 359 & J.EGPB1.XS4 & $\mathrm{AC}$ \\
\hline 318 & J.YDPB3.XS3 & & 339 & J.JA.XS4 & $\mathrm{T}$ & 360 & Section 1 above & $\mathrm{AD}$ \\
\hline 319 & J.YDPB3.XS4 & $\mathrm{J}$ & 340 & J.JA.XS40 & $\mathrm{U}$ & & split & \\
\hline 320 & J.YDPB3.XS40 & & 341 & J.JA.XS60 & & & & \\
\hline
\end{tabular}

\section{LIDAR Elevation Data}

The City and Borough of Juneau provided Light Detection and Ranging (LIDAR) elevation data (fig. 5) that were used to supplement the survey data for selected locations. Discrepancies between the field-surveyed elevations and LIDAR-obtained elevations were on the order of $0.5-1.0 \mathrm{ft}$, generally showing the LIDAR data at a lower elevation, limiting the use of LIDAR data to applications insensitive to exact elevations. Most commonly, LIDAR data were used to extend cross sections where an obvious, topographic feature was present. LIDAR data were also used to produce an extra cross section upstream from the upstream-most surveyed cross section on Jordan Creek to accommodate a lateral weir simulating overflow from the Jordan Creek network. Review of LIDAR data helped conceptualize inter-basin flow paths near Egan Drive and Glacier Highway.

\section{Channel Roughness (Manning's $n$ )}

Flood profile models require an estimate of channel and overbank roughness, which provide resistance to flow. Hydraulic roughness is characterized commonly by Manning's $n$, a coefficient that cannot be measured directly. Estimates of Manning's $n$ reflect the boundary roughness generated by bed materials, vegetation, pavement, or other surface material present, as well as other types of roughness generated by obstacles and variations in channel parameters over short distances. Empirically derived tables (for example, U.S. Army Corps of Engineers [2002b]) list Manning's $n$ for surfaces common to a developed environment, and various publications show photographs of measurement sites for the natural riverine environment (for example, Barnes [1967]). Initial estimation of Manning's $n$ for this study relied on comparison of published values for various surfaces to field observations and photographs of the channel and hydraulic 
structures. Final values were obtained from the calibration process, which involved adjustments of initial values to obtain a reasonable match of simulated water surfaces with measured water surfaces during a small flood on November 21, 2005. Final values determined from calibration were used for the full range of discharges analyzed.

The range of values of Manning's $n$ used in the model is presented in table 7. In-channel values are relatively high in many locations to reflect the presence of dense in-channel vegetation. In some locations, dense vegetation was present in the channel, but channel sideslopes were lightly vegetated and sloped up to paved sidewalks and roadways. In these instances, the channel is rougher than the overbank areas.

\section{Starting Water-Surface Elevation}

Flood conditions are conservatively assumed to coincide with a high tide. The starting water-surface elevation in the model for Duck and Jordan Creeks at the downstream end of the study reach is the high-tide elevation of $20 \mathrm{ft}$, based on analysis from the previous FIS (Federal Emergency Management Agency, 1990). This is the high tide expected during a month when the 10-, 50-, 100-, or 500-year floods are likely to occur.

Model simulation results show backwater effects from a high tide as far as $720 \mathrm{ft}$ upstream from Berners Avenue on Duck Creek and $750 \mathrm{ft}$ upstream from Yandukin Drive on Jordan Creek during a 100-year flood. Water-surface elevations downstream from these locations would be lower than the simulated flood profile if the 100-year flood coincides with a lower tide.

\section{Calibration to Known Water-Surface Elevations}

Water-surface elevations were not available to rigorously calibrate the model to the high flows for which it was designed. However, water-surface elevations surveyed for a small flood on November 21, 2005, provided an opportunity to calibrate in-channel roughness values for a lower flow. The poor results of this calibration led to a downward adjustment of final values to within published ranges for the measured conditions.
Table 7. Range of Manning's $n$ for Duck and Jordan Creeks, Alaska.

\begin{tabular}{lcc}
\hline \multicolumn{1}{c}{ Stream reach } & $\begin{array}{c}\text { Range of Manning's } \boldsymbol{n} \\
\text { for channel areas }\end{array}$ & $\begin{array}{c}\text { Range of Manning's } \boldsymbol{n} \\
\text { for overbank areas }\end{array}$ \\
\hline $\begin{array}{l}\text { Duck Creek main stem } \\
\text { Unnamed tributary to } \\
\text { Duck Creek }\end{array}$ & $0.030-0.060$ & $0.040-0.070$ \\
Jordan Creek & $0.030-0.035$ & $0.040-0.060$ \\
\hline
\end{tabular}

Model calibration involves adjusting roughness coefficients to match simulated water-surface elevations as closely as possible to measured water-surface elevations. Measured discharges during the November 21, 2005, flood were $40.9 \mathrm{ft}^{3} / \mathrm{s}$ at the USGS gaging station on Duck Creek, just greater than the 2-year flood magnitude, and $138 \mathrm{ft}^{3} / \mathrm{s}$ at the gaging station on Jordan Creek, between the 2- and 5-year flood magnitudes. For both streams, the model accounted for sediment that partially blocks the culverts (standard practice assumes sediment is scoured out for high flow, but sediment was present for the November 2005 flow). Despite the adjustment for partially blocked culverts, calibrating the model to the measured water-surface elevations required raising roughness coefficients to 0.09 , a value exceeding generally accepted published ranges of roughness coefficients for the channel conditions present.

Finalizing roughness coefficients for the desired higher flows required balancing the calibration results from the lower flow with generally accepted published ranges. Roughness coefficients were reduced to within accepted ranges while minimizing the difference in simulated and measured water levels. The maximum final in-channel roughness coefficient was 0.06 . Final simulated water-surface elevations for the November 21, 2005, flood were an average of $0.7 \mathrm{ft}$ less than measured water-surface elevations on Duck and Jordan Creeks (fig. 7). The final simulated 100-year water-surface elevation was $0.4 \mathrm{ft}$ lower than the calibrated model's 100 -year watersurface elevation simulation. Although this drop is within a $0.5 \mathrm{ft}$ tolerance for the model, it indicates that the actual 100-year water-surface elevations could be slightly higher than simulated water-surface elevations. 

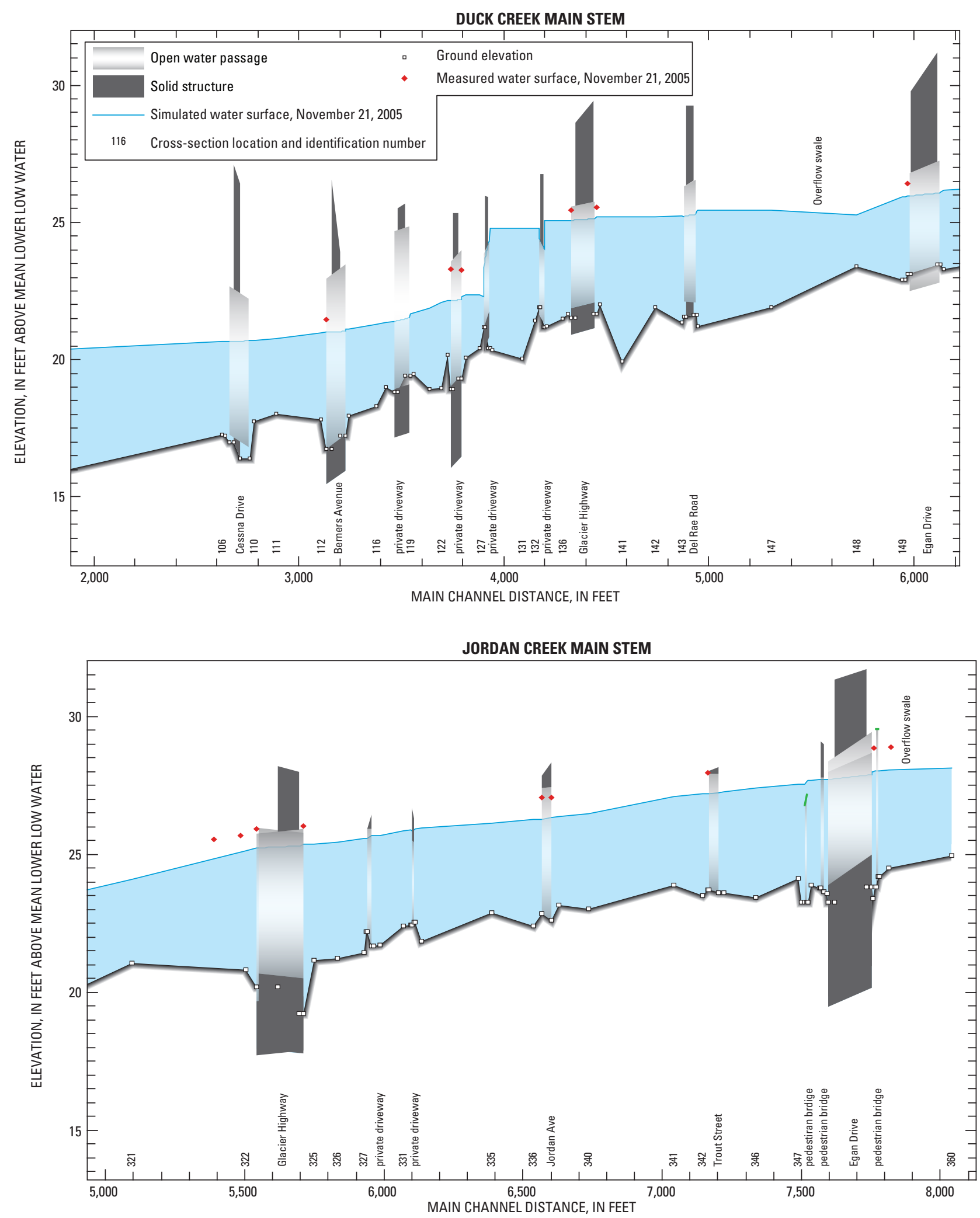

Figure 7. Profile of simulated water-surface elevations and measured water-surface elevations for flow in Duck and Jordan Creeks, Juneau, Alaska, November 21, 2005. 


\section{Flood Profiles}

Flood profiles computed for Duck Creek and Jordan Creek downstream from Egan Drive consist of the watersurface elevation for the 10-, 50-, 100-, or 500-year floods (fig. 8A-E). The model assumes Duck and Jordan Creeks peak simultaneously, and flooding coincides with a $20 \mathrm{ft}$ high tide. Sensitivity analysis indicates the accuracy of the water-surface elevations is within the required tolerance of $0.5 \mathrm{ft}$.

Actual flooding conditions can damage bridges, culverts, and roadways, and debris obstructions can increase local flooding. However, this study assumes that all structures included in the model maintain their integrity during floods, that no road failures occur, and that structures remain unobstructed. For most culverts, the model assumes sediment observed during field investigations is washed out during flooding.

The steady-state model used does not address the possible attenuating effects of the numerous ponds within the Duck and Jordan Creek corridors. The likely effect of an unsteady-flow analysis, which would address storage, would be a reduction in water-surface elevations.

Generally, the lateral extent of the water-surface for the cross sections adequately delineates the flood plain. However, cross sections do not extend to the full extent of the 500 -year flood plain in areas where it was impractical to do so and the extension would not affect the model hydraulics. In particular, cross sections do not extend fully at locations where the channel flows over roadways and along Jordan Creek between Egan Drive and Glacier Highway, where watersurface elevations exceed the elevation of the surrounding land surface. Flood plains in these areas may be delineated on the basis of elevations generated in the model.

Simulated water-surface profiles generally are higher than those published previously (Federal Emergency Management Agency, 1990), showing a 1- to 3-ft discrepancy in elevation at the limits of the study areas for the 100-year flood (table 8). Possible reasons for this discrepancy include new hydrologic data, different assumptions regarding storage, different survey datum, and land-surface elevation change over time. A re-analysis of Jordan Creek upstream from Egan Drive will be necessary to match the profiles shown in this report. The profiles downstream from the underground pipe for the tributary named East Fork Duck Creek in the previous FIS will need adjustment because the simulated water surface at the confluence is about $3 \mathrm{ft}$ higher than in the previous FIS.

\section{Inter-Basin Flow}

The Duck and Jordan Creek flood plains merge downstream from Egan Drive for the 50-, 100-, and 500-year floods. The LIDAR data show a low area along the east bank of Duck Creek about $500 \mathrm{ft}$ downstream from Egan Drive (fig. 9). Floodwaters exceeding the elevation of this area (modeled as $29.0 \mathrm{ft}$ ) will not return to Duck Creek, but instead will flow across a residential landscape to Jordan Creek. The simulated 100-year flood conditions show a flow of $22 \mathrm{ft}^{3} / \mathrm{s}$ exiting Duck Creek and entering Jordan Creek upstream from Jordan Avenue (table 5).

A topographic low between the base of the Mendenhall Valley wall and Egan Drive extends to the southeast from Jordan Creek for about 4,000 ft (fig. 9). Floodwaters exceeding the elevation of this low (simulated as $29.5 \mathrm{ft}$ ) will exit the Jordan Creek system entirely and drain into salt water. Model simulation results show a flow of $104 \mathrm{ft}^{3} / \mathrm{s}$ would exit Jordan Creek during the 100-year flood.

\section{Discussion}

Combined flows at the mouths of Duck and Jordan Creeks for the 100-year flood are $467 \mathrm{ft}^{3} / \mathrm{s}$, with $106 \mathrm{ft}^{3} / \mathrm{s}$ leaving the Jordan Creek network upstream from Egan Drive (table 5). This is considerably less than the $699 \mathrm{ft}^{3} / \mathrm{s}$ simulated in the previous FIS (Federal Emergency Management Agency, 1990). However, simulated profiles generally are higher than those for the previous study. The effect of these differences on the areal extent of the flood plain depends on the topographic data used during flood plain delineation and cannot be predicted from this study alone.

The strong influence of culverts and bridges can be seen in the stair-step profiles for the 100-year flood on Duck Creek, which are influenced by backwater from near Berners Avenue upstream to Cinema Drive (fig. 8A-B ). As viewed moving upstream over this $1.5 \mathrm{mi}$ reach, the water-surface elevation increases at culverts and bridges, then remains flat until the next structure is reached. Under the influence of this backwater, the presence of some smaller structures has no noticeable effect on the water-surface profile. A similar effect can be seen at culverts at Glacier Highway and Egan Drive along Jordan Creek (fig. 8E). 


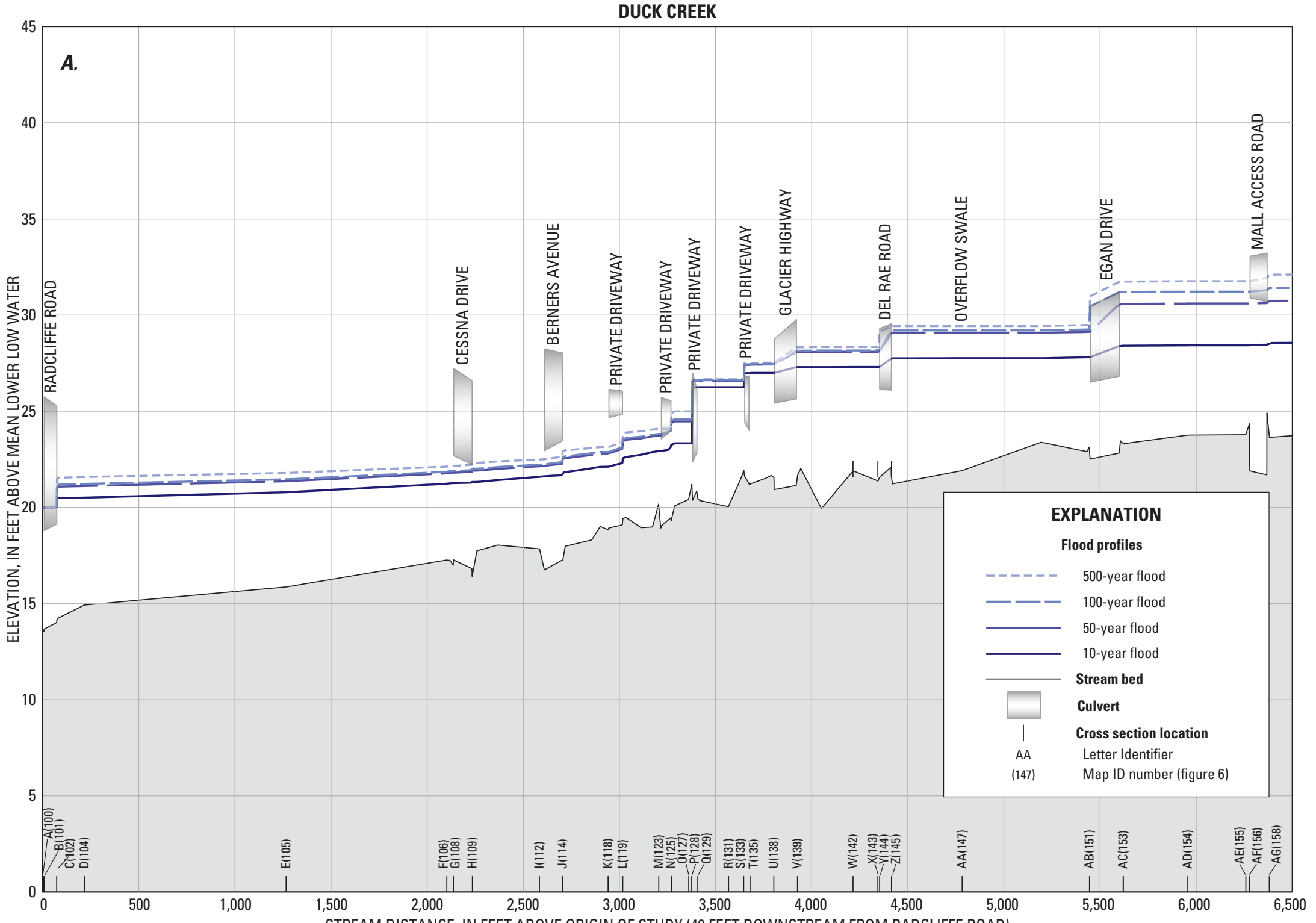

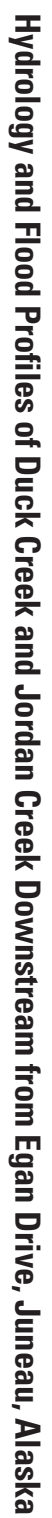

Figure 8. Flood profiles for Duck and Jordan Creeks, and unnamed tributary to Duck Creek, Juneau, Alaska. 


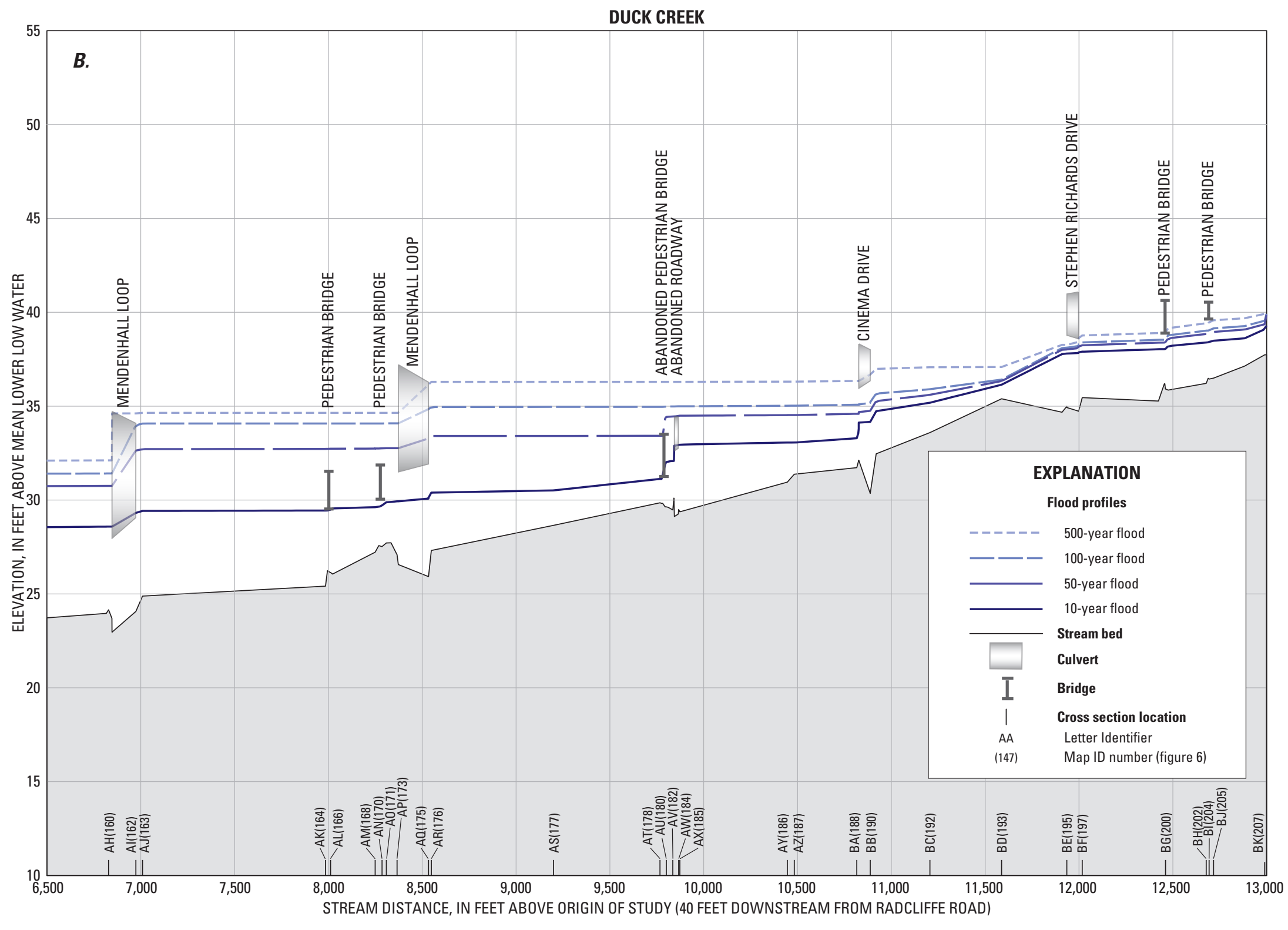

Figure 8.-Continued. 


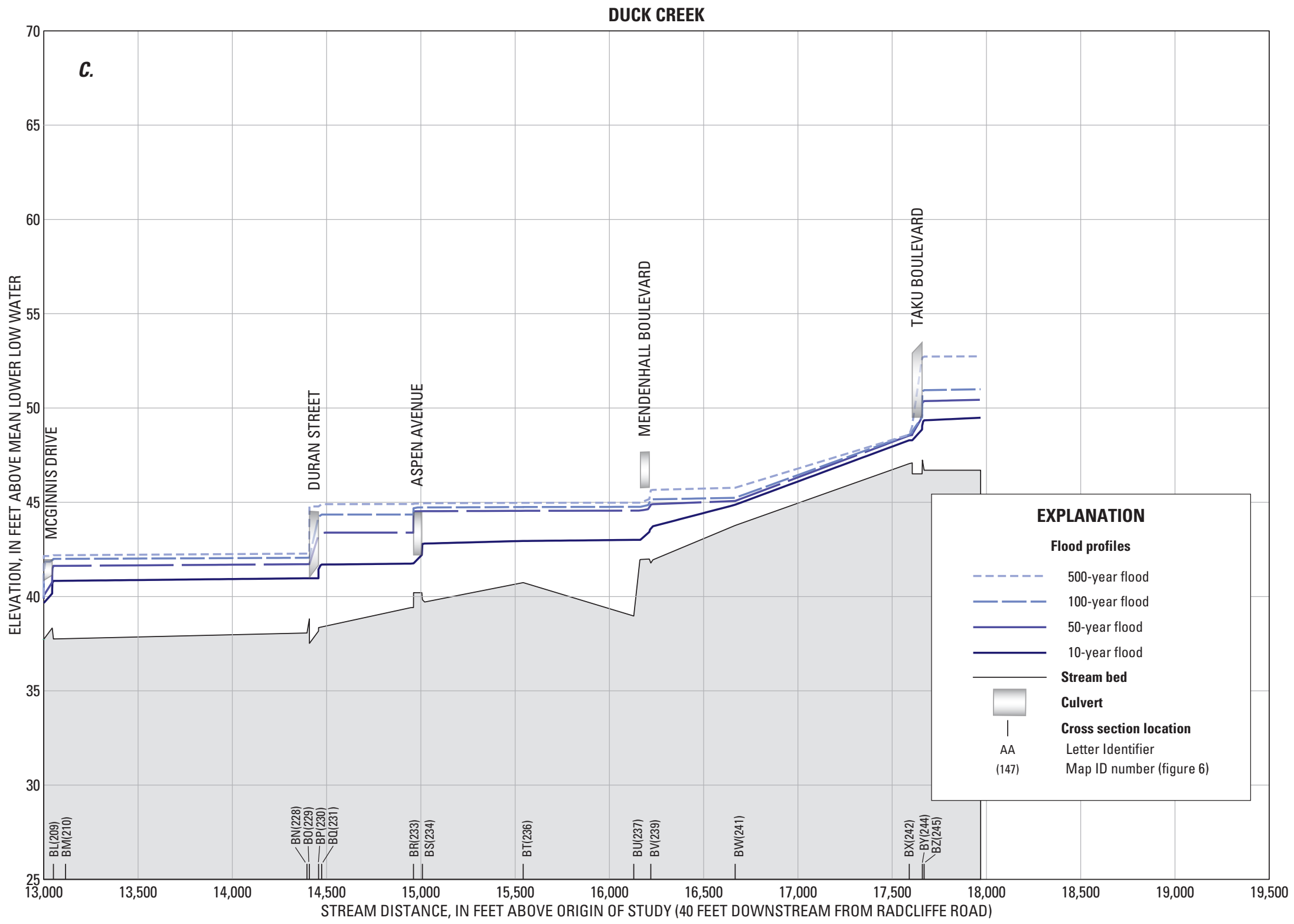

Figure 8.-Continued. 


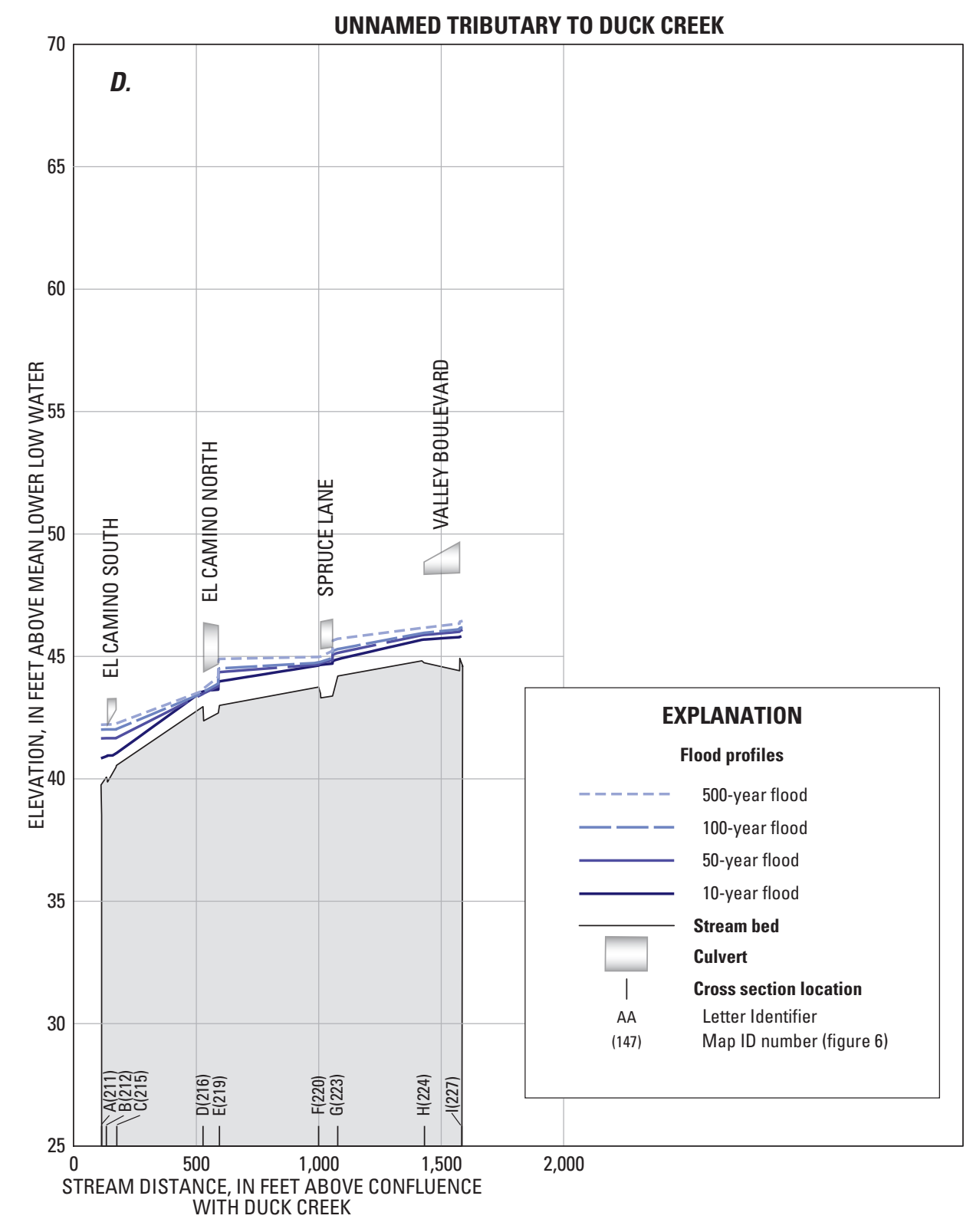

Figure 8.-Continued. 
JORDAN CREEK

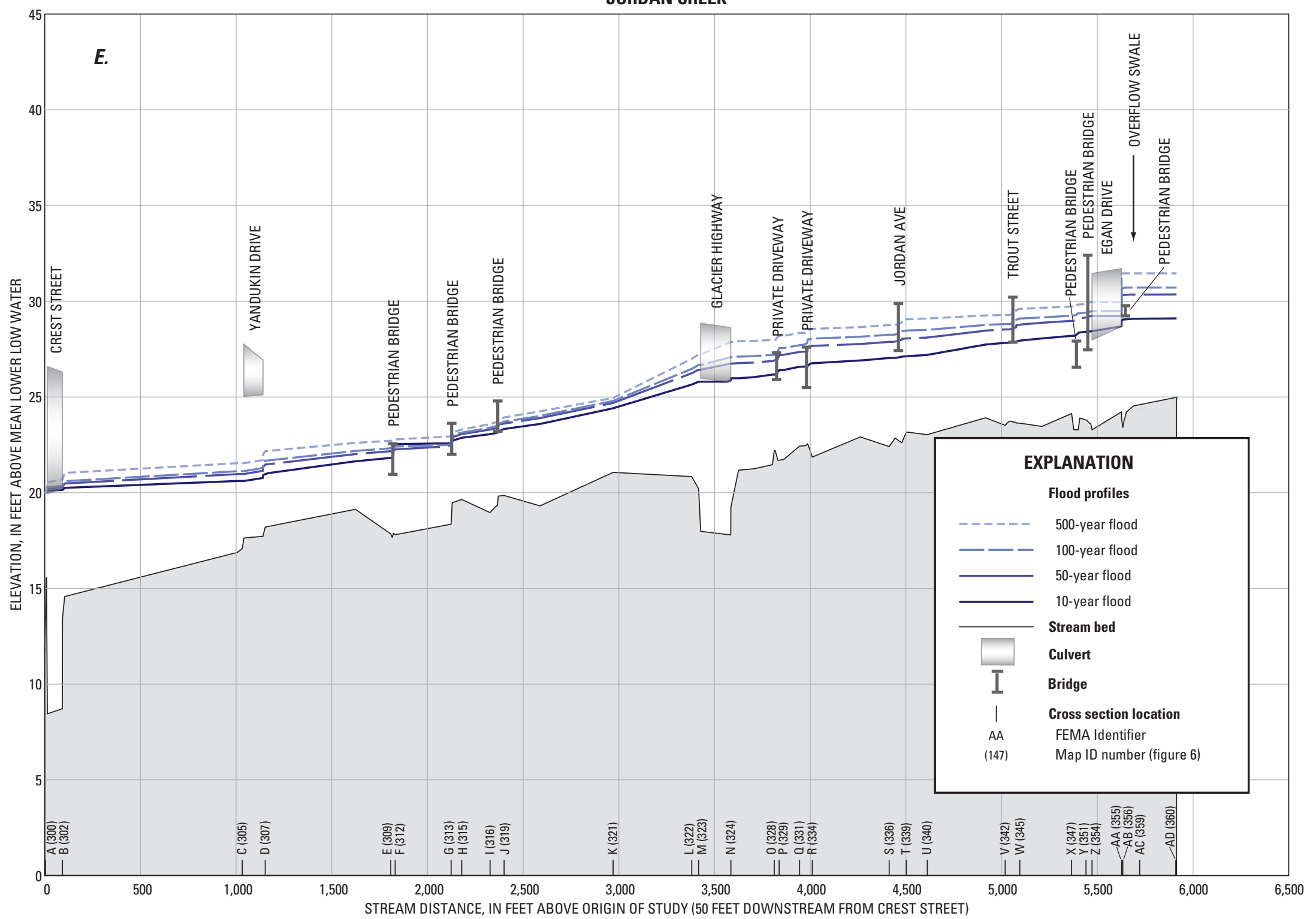

Figure 8.-Continued. 


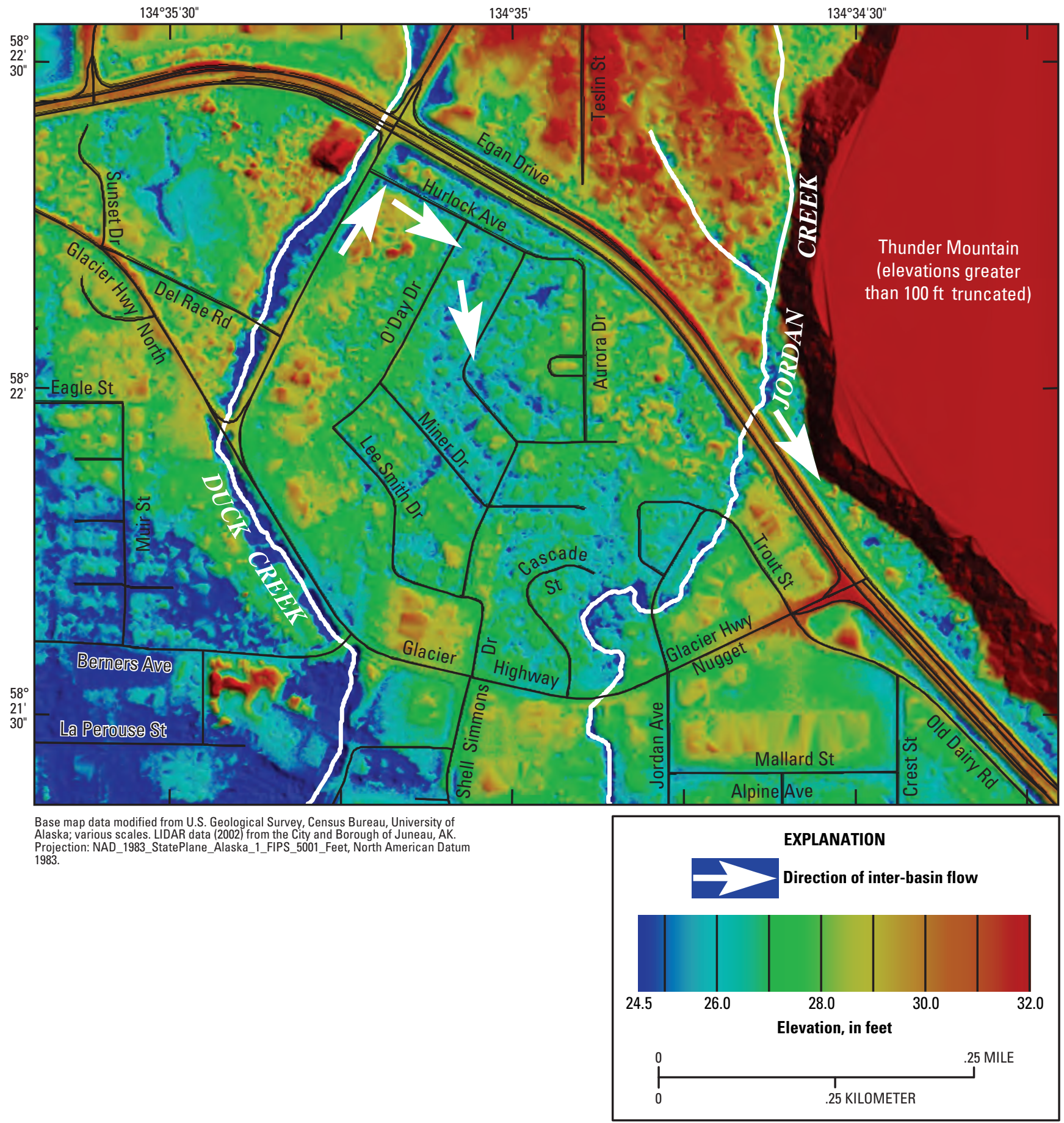

Figure 9. Modeled stream center lines, roads, general elevation data, and direction of inter-basin flow for Duck and Jordan Creeks between Egan Drive and Glacier Highway in Juneau, Alaska. 
Table 8. Comparison of flood profiles at limits of study area to adjacent published profiles, Duck and Jordan Creeks, Juneau, Alaska.

[Abbreviations: FEMA, 1990, Federal Emergency Management Agency, 1990; ft, foot]

\begin{tabular}{ccc}
\hline Flood profile & $\begin{array}{c}\text { Water-surface } \\
\text { elevation in current } \\
\text { study (ft) }\end{array}$ & $\begin{array}{c}\text { Water-surface } \\
\text { elevation in FEMA, } \\
\mathbf{1 9 9 0} \text { (ft) }\end{array}$ \\
\hline \multicolumn{2}{c}{ Duck Creek, downstream from confluence with } \\
tributary near Nancy Street (15053200) \\
\hline 500-year & 31.5 & 29.8 \\
100-year & 30.7 & 29.4 \\
50-year & 30.4 & 29.1 \\
10-year & 29.1 & 28.2 \\
\hline Jordan Creek, upstream from Egan Drive (15052475) \\
\hline 500-year & 31.5 & 29.8 \\
100-year & 30.7 & 29.4 \\
50-year & 30.4 & 29.1 \\
10-year & 29.1 & 28.2 \\
\hline
\end{tabular}

\section{Summary}

Duck and Jordan Creeks are small, urban streams that flow through closely-spaced engineered bridges and culverts in Juneau's Mendenhall Valley before draining into salt water. Both streams drain areas along the steep eastern flank of the valley. However, Jordan Creek extends farther up the mountainside and collects more mountainous drainage than Duck Creek, which first becomes channelized in the valley floor and is more influenced by ground-water conditions. Jordan Creek's drainage area is 2.6 square miles, twice the size of Duck Creek's drainage area, and its peak flows are about 3 times larger than Duck Creek's.

To provide information for updating Juneau's most recent flood insurance study, this study determined flood magnitudes for floods with a 2-, 5-, 10-, 25-, 50-, 100-, 200-, and 500-year recurrence interval on Duck and Jordan Creeks. Computations from 11 and 8 years of streamflow data on Duck and Jordan Creeks, respectively, were weighted with results from regional regression equations for southeast Alaska. The flood discharges were used together with field surveys of channel geometry and details of culverts and bridges to construct a steady-state hydraulic model using the U.S. Army Corps of Engineers' HEC-RAS software. Simulated reaches include 3.4 miles of main stem Duck Creek, 0.3 mile of an unnamed tributary to Duck Creek near McGinnis Street, and 1.1 miles of Jordan Creek downstream from Egan Drive. Additional work will be required to update Jordan Creek upstream from Egan Drive. The model was calibrated by adjusting Manning's roughness coefficients so water-surface elevations more closely matched measured elevations from a small 2005 flood. Resulting flood profiles provide water-surface elevations for the 10-, 50-, 100-, and 500-year floods. These flood profiles are strongly affected by backwater from the 30 culverts and bridges on Duck Creek and the 14 culverts and bridges in the study area on Jordan Creek. Backwater conditions over much of the study area create a stair-step profile with watersurface elevations rising at the culvert or bridge and a flat water-surface profile extending upstream. Inter-basin flow was simulated in two locations, one leaving Duck Creek downstream from Egan Drive and entering Jordan Creek upstream from Jordan Avenue, and another leaving the Jordan Creek system entirely in a southeast trending depression along the upstream side of Egan Drive.

\section{References Cited}

Barnes, H.H., Jr., 1967, Roughness characteristics of natural channels: U.S. Geological Survey Water-Supply Paper $1849,213 \mathrm{p}$.

City and Borough of Juneau, Alaska, 2001, Community demographics 2001 Juneau population map: City and Borough of Juneau, Alaska, accessed March 2, 2006, at http://www.juneau.org/cddftp/demographics/2001 CBJ Pop map.pdf

Curran, J.H., Meyer, D.F., and Tasker, G.D., 2003, Estimating the magnitude and frequency of peak streamflows for ungaged sites on streams in Alaska and conterminous basins in Canada: U.S. Geological Survey Water-Resources Investigations Report 03-4188, 101 p., accessed October 3, 2006, at http://pubs.water.usgs.gov/wri034188

Federal Emergency Management Agency, 1990, Flood insurance study, City and Borough of Juneau, Alaska: Federal Emergency Management Agency, 42 p., 36 p. figs.

Interagency Advisory Committee on Water Data, 1982, Guidelines for determining flood flow frequency: Hydrology Subcommittee Bulletin 17B, 28 p., 14 app. 
Jones, S.H., and Fahl, C.B., 1994, Magnitude and frequency of floods in Alaska and conterminous basins of Canada: U.S. Geological Survey Water-Resources Investigations Report 93-4179, 122 p., 2 pls.

National Geodetic Survey, 2006, NGS datasheet page: National Geodetic Survey data available on the Web, accessed May 3, 2006, at http://www.ngs.noaa.gov/cgi-bin/ datasheet.prl

Neal, E.G., 2006, Channel incision of proglacial Mendenhall River and implications to Mendenhall Valley hydrology [abs.]: Anchorage, Alaska, Proceedings of the 2006 Alaska American Water Resources Association, Water and Restoration Conference.

Neal, E.G., and Host, R.H., Hydrology, geomorphology, and flood profiles of the Mendenhall River, Juneau Alaska: U.S. Geological Survey Water-Resources Investigations Report 99-4150, $35 \mathrm{p}$.

Trimble Navigation Limited, 1999, Trimble Geomatics Office Software User Guide: Trimble Navigation Limited, v. 1.00, rev. A, v. 1 and 2, variously paged.
U.S. Army Corps of Engineers, 2002a, HEC-RAS river analysis system user's manual, ver. 3.1: Hydrologic Engineering Center CPD-68, variously paged.

U.S. Army Corps of Engineers, 2002b, HEC-RAS river analysis system hydraulic reference manual, ver. 3.1: Hydrologic Engineering Center CPD-69, variously paged.

U.S. Army Corps of Engineers, 2002c, HEC-RAS river analysis system applications guide, ver. 3.1: Hydrologic Engineering Center CPD-70, variously paged.

U.S. Geological Survey, 2002, Water resources application software, PEAKFQ, ver. 4.1: U.S. Geological Survey data available on the Web, accessed May 3, 2006, at http://water. usgs.gov/software/surface water.html

U.S. Geological Survey, 2006, National water information system, USGS water data for Alaska: U.S. Geological Survey data available on the Web, accessed May 3, 2006, at http://waterdata.usgs.gov/ak/nwis

U.S. Geological Survey, undated, U.S. GeoData for Alaska: U.S. Geological Survey data available on the web, accessed May 3, 2006, at http://agdc.usgs.gov/data/usgs/to geo.html 
This page intentionally left blank. 


\section{Appendix A. Description of Temporary Benchmarks Placed for Survey, and Benchmarks Placed by Others and Used in Survey}


This page intentionally left blank. 


\section{Appendix B. Coordinates and Elevations for Surveyed Points, Duck and Jordan Creeks, Alaska}

Appendix B data are available in an Excel data base for download at URL:

http://pubs.water.usgs.gov/sir20065323/ sir20065323 appb.xls. 
Manuscript approved for publication, December 28, 2006

Prepared by the USGS Publishing Network,

Publishing Service Center, Tacoma, Washington

Bill Gibbs

Debra Grillo

Jacqueline Olson

Bobbie Jo Richey

Sharon Wahlstrom

Cheri Yoesting

For more information concerning the research in this report, contact the Alaska Science Center

U.S. Geological Survey

4230 University Drive, Suite 201

Anchorage, Alaska 99508-4664

http://alaska.usgs.gov 


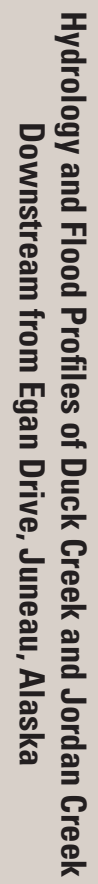

